University of Louisville

ThinkIR: The University of Louisville's Institutional Repository

$12-2010$

\title{
Quality teaching in addressing student achievement : a comparative study between national board certified teachers and other teachers on the Kentucky Core Content Test results.
}

Harrie Lynne Buecker 1952-

University of Louisville

Follow this and additional works at: https://ir.library.louisville.edu/etd

\section{Recommended Citation}

Buecker, Harrie Lynne 1952-, "Quality teaching in addressing student achievement : a comparative study between national board certified teachers and other teachers on the Kentucky Core Content Test results." (2010). Electronic Theses and Dissertations. Paper 176.

https://doi.org/10.18297/etd/176

This Doctoral Dissertation is brought to you for free and open access by ThinkIR: The University of Louisville's Institutional Repository. It has been accepted for inclusion in Electronic Theses and Dissertations by an authorized administrator of ThinkIR: The University of Louisville's Institutional Repository. This title appears here courtesy of the author, who has retained all other copyrights. For more information, please contact thinkir@louisville.edu. 
QUALITY TEACHING IN ADDRESSING STUDENT ACHIEVEMENT: A COMPARATIVE STUDY BETWEEN NATIONAL BOARD CERTIFIED TEACHERS AND OTHER TEACHERS ON THE KENTUCKY CORE CONTENT TEST RESULTS

By

Harrie Lynne Buecker

B.S., University of Louisville, 1976

M.Ed., University of Louisville, 1981

\author{
A Dissertation \\ Submitted to the Faculty of the \\ Graduate School of the University of Louisville \\ In Partial Fulfillment of the Requirements \\ for the Degree of
}

Doctor of Philosophy

Department of Teaching and Learning

University of Louisville

Louisville, Kentucky

December 2010 
QUALITY TEACHING IN ADDRESSING STUDENT ACHIEVEMENT: A COMPARATIVE STUDY BETWEEN NATIONAL BOARD CERTIFIED TEACHERS AND OTHER TEACHERS ON THE KENTUCKY CORE CONTENT TEST RESULTS

By

Harrie Lynne Buecker

B.S.E. University of Louisville, 1976

M.Ed., University of Louisville, 1981

A Dissertation Approved on

November 16, 2010

By the following Dissertation Committee

$\overline{\text { Dr. Diane Kyle, Dissertation @o-Director }}$

$\overline{\text { Dr. Ann Larsón, Dissertation Co-Director }}$

Dr. W. Blake Haselton

Dr. Joseph Petrosko

Dr. Margaret Pentecost 


\section{DEDICATION}

This dissertation is dedicated to my son, daughter, and granddaughters

Peter Jonathan Buecker, MD

Elizabeth Lynne Buecker

Cecelia Paige Buecker

Annelise Reed Buecker

who are the loves of my life and my source of inspiration. 


\section{ACKNOWLEDGMENTS}

I would like to thank my committee co-directors, Dr. Diane Kyle and Dr. Ann Larson, for their continued encouragement, guidance, and patience. I would also like to thank committee members, Dr. Joe Petrosko and Dr. Margaret

Pentecost, who have so kindly assisted me in completing my dissertation. I also want to extend my appreciation to Dr. Blake Haselton, who has supported me over the past fourteen years. He has served as a mentor, supervisor, and friend. I especially wish to thank my mother, Flora Gray, my father, the late Harry Lucas, and my sister, Ramona Lucas. They have throughout the years motivated me to be all that I can be. 


\begin{abstract}
QUALITY TEACHING IN ADDRESSING STUDENT ACHIEVEMENT:

A COMPARATIVE STUDY BETWEEN NATIONAL BOARD CERTIFIED TEACHERS and OTHER TEACHERS ON THE KENTUCKY CORE CONTENT TEST RESULTS

Harrie Lynne Buecker
\end{abstract}

November 16, 2010

This dissertation focused on the link between quality teaching and its potential impact on student achievement. National Board Certification is used to represent quality teaching and student achievement is measured by the Kentucky Core Content Test. Data were gathered on the reading and mathematics scores of students of National Board Teachers who were certified in literacy, early childhood generalist, or middle childhood generalist. These scores were compared to students assigned to teachers who were not National Board Certified Teachers.

This dissertation is comprised of five chapters. Chapter One provides an overview of the dissertation and establishes the rationale for the importance of the research. Chapter Two serves as a review of the pertinent literature related to similar studies which link National Board Certification to student results on state assessments, as well as research supporting the theoretical basis for the dissertation. Chapter Three focuses on the multi-level model of statistical analysis used in the study. This includes the number of years of experience the 
teachers have, the number of years the teachers have held National Board Certification. Also included were demographic information on the students (free lunch eligibility and ethnicity). An existing data set of scores on the Kentucky Core Content Test was used to analyze the achievement scores for students and an existing data set of National Board Certified Teachers in Kentucky was used to randomly identify the teachers for the study.

Chapter Four includes a discussion on the findings of the study as well as information related to the statistical significance of the analysis of data. The analysis of the data did not indicate any statistically significant difference between the student scores of National Board Certified Teachers (NBCTs) and the student scores of teachers who were not National Board certified.

And finally, Chapter Five includes a summary of the results of the study and links the findings of the study to its significance to professional practice and recommendations for future research. The chapter also provides a detailed discussion of each of the two specific research questions. 


\section{TABLE OF CONTENTS}

PAGE

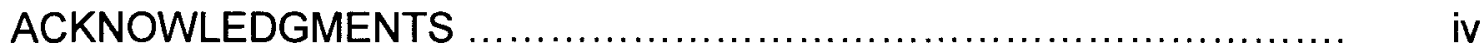

ABSTRACT

$\mathrm{v}$

LIST OF TABLES

\section{CHAPTER}

I. QUALITY TEACHING IN ADDRESSING STUDENT

ACHIEVEMENT: A COMPARATIVE STUDY BETWEEN

NATIONAL BOARD CERTIFIED TEACHERS AND OTHER

TEACHERS ON THE KENTUCKY CORE CONTENT TEST

RESULTS

Introduction

Problem Statement

Purpose of the Study

Significance of This Study

Research Questions

Limitations of the Study

Definitions

Conceptual Framework

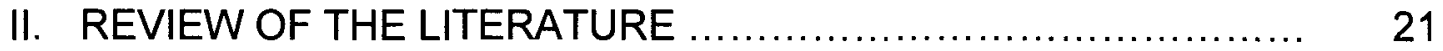

Student Achievement Accountability .......................... 21

Quality Teaching ................................................ 25

Assessing Quality Teaching ................................... 33

National Board for Professional Teaching Standards (NBPTS) .. $\quad 36$

NBPTS Studies

III. METHOD

Design of the Study 
Sample .......................................................... 57

Data Collection ............................................... 58

Data Analysis ............................................... 59

Variables Measured on Teachers .......................... 62

Variables Measured on Students ............................ 62

Statistical Analysis ........................................... 62

Limitations .................................................... 63

Conclusion .................................................... 64

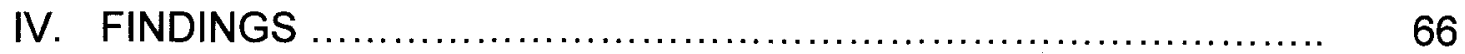

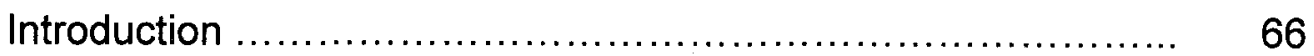

Participant Demographics ....................................... 66

Results ...................................................... 67

Descriptive Statistics on Study Variables ..................... 67

Inferential Statistical Tests Related to Reading and

Mathematics Performance ....................................... 69

Randomized MANOVA, ANOVA and ANCOVA on

Individual Student Data ...................................... $\quad 70$

Inferential Statistical Tests Related to Reading and

Mathematics Performance

Randomized MANOVA, ANOVA and ANCOVA on Individual Student Data

ANOVA and ANCOVA on Aggregated Data ............... 73

Additional Tests of Study Variables

Correlation of Teaching Experience, Years Certification

and Student Performance

Multiple Regression of Individual Reading and

Mathematics Scores

76

Socioeconomic Status Effects on Test Scores ................ 77

Comparison of Study Data with Commonwealth of

Kentucky Average Scale Scores

Random Effects of ANOVA of Reading and Mathematics ..... $\quad 79$

Summary of the Data Analysis

80

V. SUMMARY AND CONCLUSIONS

Recommendations 
TABLE OF CONTENTS (continued)

CHAPTER

PAGE

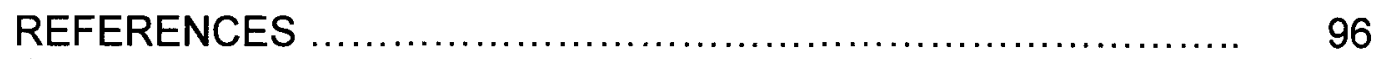

CURRICULUM VITAE ......................................... 101 


\section{LIST OF TABLES}

TABLE

PAGE

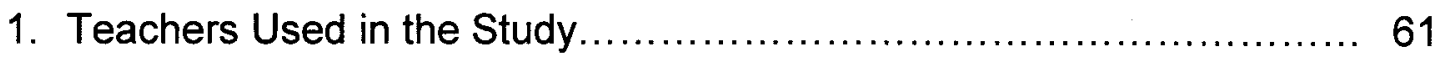

2. Frequency Distributions for Student Variables......................... 68

3. Descriptive Statistics for Student Scores ................................. 70

4. Descriptive Statistics for Socioeconomic Status....................... 72

5. Descriptive Statistics_Mean and Standard Deviation.................. 74

6. Summary of Inferential Statistical Tests................................ 75

7. Comparison of Grade 3 KCCT Reading and Mathematics

Scores with Commonwealth of Kentucky Average Scores.............. 79 


\section{CHAPTER I}

\section{QUALITY TEACHING IN ADDRESSING STUDENT ACHIEVEMENT: A COMPARATIVE STUDY BETWEEN NATIONAL BOARD CERTIFIED TEACHERS AND OTHER TEACHERS ON THE KENTUCKY CORE CONTENT TEST RESULTS \\ Introduction}

The newest wave of education reform seems most related to quality teaching and student outcomes. Emerging research points to the essential link between capable teaching practices and resulting student achievement. Lowachieving students require the most effective teachers, yet the traditional school culture and practices tend to assign the most effective teachers to the highest achievers (Sanders, 1996; Barber, 2008).

The United States has raised the bar for student achievement and issued a mandate to narrow the achievement gap between all students regardless of socioeconomic status, ethnicity, race, or gender (United States Department of Education, 2002). The Department of Education began the implementation of

the bipartisan passage of No Child Left Behind (NCLB) Act in 2002. In essence, this law seeks to guarantee a successful education for each child enrolled in America's public schools through instruction by highly qualified teachers. The law includes language which holds schools accountable for the achievement of 
all students in reading and mathematics by linking the performance of all students on state assessments to meeting Adequate Yearly Progress (AYP). NCLB also includes a mandate for providing quality teachers for all students and quality teaching has become a political issue. The high stakes accountability placed upon schools through the NCLB Act has elevated the focus of research on teacher quality and quality teaching as well (United States Department of Education, 2002).

Kentucky had raised the bar on high stakes accountability with the passage of the Kentucky Education Reform Act (KERA) on July 13, 1990. This was the result of a lawsuit filed by the Council for Better Education, made up of 66 Kentucky school districts, against the state for failing to provide for an "efficient" education for all Kentucky's students. Four of KERA's key components included high goals which articulated the expectations of graduates; a rigorous assessment process which measured the students' progress toward meeting those goals; an accountability system which rewarded schools meeting their target goals and sanctioned schools failing to make adequate progress; and funding specifically for the purpose of professional development for teachers to learn effective instructional strategies (Legislative Research Commission, 1994). Over the course of the next decade, effective instructional strategies became inextricably linked with quality teaching and teacher quality.

Teacher quality has many dimensions including content knowledge and effective pedagogical use. Some may argue that the best indicator of teacher quality is assessed by student outcomes, such as student assessment results on 
state tests typically given at the end of a school year (Darling-Hammond \& McLaughlin, 2000).

While most would agree that every child in our country deserves the opportunity to learn from a quality teacher, continued diminished funding for education across the states makes the reality of the spirit of NCLB a challenge. State leaders are struggling to provide the financial and human resources necessary for making the goals of NCLB a reality for America's children. In some cases, there are a limited number of teachers holding certification in specific content areas. There has also been discussion related to additional compensation for teachers certified in mathematics and science, as well as merit pay for those teaching in high risk areas (Darling-Hammond \& McLaughlin, 2000).

Many researchers have concluded that the differential effectiveness of the classroom teacher was the most significant determinant in learning, significantly more than the impact of socioeconomic status and class size (Sanders \& Rivers, 1996; Sanders \& Horn, 1998; Darling-Hammond \& McLaughlin, 2000; Haycock, 2001; Barber, 2008). For example, students receiving instruction from teachers considered to be effective have achieved at significantly higher levels than those students assigned to less effective teachers (Sanders \& Rivers, 1996; Barber, 2008).

In an attempt to elevate teaching effectiveness, one of the earliest models to address quality teaching was the National Board for Professional Teaching Standards (NBPTS), who established National Board Certification (NBPTS, 
2007). This effort was fueled in part by the Carnegie Task Force on Teaching as a Profession (1986), which called for the creation of a new type of certification for teachers, aside from state certification, by a nonprofit organization which measured the demonstrated competencies and skills of accomplished teachers. This certification involves a voluntary process of a highly rigorous performancebased series of assessments which are aligned with the NBPTS standards: an initial screening to verify eligibility, completion of four portfolio entries, and successful responses to six on-demand assessment exercises (NBPTS, 2007). Authors of three studies with large samples, Goldhaber and Anthony; Vandervoort, Amrein-Beardsley, and Berliner; and Cavalluzo all concluded that increased student achievement is related to National Board Certification (Goldhaber \& Anthony, 2004; Vandervoort, Amrein-Beardsley \& Berliner, 2004); Cavalluzo, 2004). Goldhaber and Anthony (2004) reported that the NBPTS certification is indeed identifying effective teachers. They found that "NBPTS certified teachers are more effective, and unsuccessful NBPTS applicants are generally more effective than teachers who never applied to the program" (Goldhaber \& Anthony, 2004, p. 142). These researchers concluded that NBCTs increased the teaching quality and achievement, particularly with minority students (Goldhaber \& Anthony, 2004).

On the other hand, another large study conducted in North Carolina by Sanders, Ashton, and Wright (2005) compared NBCTs to non-NBCTs by comparing fourth- and fifth-grade reading and mathematics end of year tests in Phase I of their research. The findings revealed no significant pattern of student 
achievement effects. However, there were fewer NBCTs than the comparison group of fifth grade teachers included in the sample (Sanders, Ashton, \& Wright, 2005).

Because quality teaching is identified by the literature as the dominant factor in student achievement, and the NBPTS certification assesses what accomplished teachers should know and be disposed to do, many studies have been undertaken to measure the impact of National Board Certification on student achievement and quality teaching in the nation's schools (NBPTS, 2009). Several of these studies are discussed in detail in chapter two. However, none was conducted in Kentucky which examines the direct impact of NBCTs on student achievement. This suggests the importance and contributions of this study, which examined the connections between Kentucky teachers certified by the NBPTS and the reading and mathematics scores of their students on the state assessment.

\section{Problem Statement}

This study examined the effects of teacher quality on student achievement in reading and mathematics by focusing on quality teaching practices identified by the NBPTS. These professional practices have been identified through a framework for teaching, including the knowledge and skills necessary in providing meaningful instruction for diverse student populations and the standards established by the National Board for Professional Teaching Standards (NBPTS, 2009). While some critics have voiced concerns about the costs associated with this advanced certification, many believe that this process 
is valid in acknowledging the complexities underlying quality teaching. The NBPTS assessments measure the candidates' content knowledge and require them to compile student work samples with an explanation of how they assessed the work and how they documented student progress in the related assignments (NBPTS, 2009).

In order to be eligible for pursuit of certification through the NBPTS, teachers must have completed a minimum of three years of teaching experience. In Kentucky, teachers may earn a Rank I, which equals 45 graduate hours, if they have also obtained a Master's degree status prior to being certified by the National Board. This is not a common practice in other states. The state provides a mandated stipend of $\$ 2,000$, although some districts pay NBCT's an additional stipend. The combination of the salary advancement of Rank I along with the NBCT stipend, results in a significant salary raise for Kentucky's NBCTs.

Effective July 14, 2000, the General Assembly in Kentucky published goals and findings related to National Board Certification. According to KRS 161.131, the legislative findings include student achievement can be directly linked to the competency and skills of the teachers; every student is entitled to be taught by teachers who demonstrate content knowledge and who can monitor and manage student learning; and that NBCTs help professionalize the teaching profession in their schools through assisting, advising, and mentoring teachers who are new to the profession; and NBCTs "serve as role models and master teachers to student teachers and by assisting other experienced teachers who 
seek National Board Certification" (Kentucky Education Professional Standards Board, 2009, Acts chapter 257, section 1).

While North Carolina ranks number one in the United States in the number of NBCTs, Kentucky currently ranks number 12 in the nation on the number of NBCTs. There are currently 1,829 NBCTs in Kentucky's schools (NBPTS, 2009). Kentucky is clearly investing significant funding in support of its NBCTs.

"National Board Certification is recognized as a model of pay-per-performance and is supported by teachers and administrators nationwide" (Odden \& Kelly, 1997).

The NCLB Act (2001) mandates that all students in grades three through eight be tested annually in the content areas of reading and mathematics. Schools must increase student achievement levels toward a specified goal, reduce the number of students performing at the novice level, and reduce the achievement gap between specific student sub populations and Caucasian students (Kentucky Department of Education, 2010).

The 2008 General Assembly in Kentucky passed legislation known as Senate Bill 1 (SB 1), which mandated a major revision of the state's curriculum standards and the Kentucky Core Content Test previously established by KERA in 1990. Senate Bill 1 also linked teacher and principal evaluations to growth in student achievement. The new state assessment system, according to SB 1, would start in 2012 , and would be bridged by an interim assessment period between 2009 and 2011. The interim period would include a criterion referenced test in $\mathbf{2 0 0 9}$ and would add a norm-referenced test to be administered in the 
spring of 2010. The results of the norm-referenced test will be utilized as a baseline for longitudinal student data for 2011 and beyond. However, the state assessment in 2009 was limited to a criterion referenced test. A norm-reference assessment was delayed until 2010 . The results of the criterion referenced test were the only assessment data available for the purposes of this study (Kentucky Department of Education, 2010).

In this study, reading and mathematics scale scores from the 2009 Kentucky Core Content Test (KCCT) were used as a measure of student achievement. This was due to the absence of a norm-referenced assessment in 2009 due to Senate Bill 1. The KCCT performance scores on both of these content areas were used as accountability indicators for the NCLB mandate (Kentucky Department of Education, 2010). In order for schools and districts to meet AYP for the NCLB goals, students must have met or exceeded the target scores, which represent the minimum improvement that is required of each district and school over the school year. Schools must also have demonstrated significant improvement in narrowing the achievement gap for students considered to be in at-risk populations, such as students with disabilities, minority students, and students eligible for the federal free lunch program (United States Department of Education, 2002).

The reading and mathematics scale scores of third-grade students on the Kentucky Core Content Test were used in this study because in Kentucky, grade three represents the exit from primary to intermediate grades. The goal for 
third-grade students is to exit the primary grades, kindergarten through grade three, at or above grade level in reading and mathematics (Kentucky Department of Education, 2010). NCLB also requires states to progress toward all students scoring at the proficient level by the year 2014 (United States Department of Education, 2002).

The reading and mathematics assessments are comprised of a combination of open response questions and multiple choice questions. The open response questions and the multiple choice questions each account for $50 \%$ of the raw scores. The open response questions are scored on a four-point scoring rubric, scores of zero to four, and multiple choice questions are either correct or incorrect, a score of zero or one. Each test includes six open response questions and $\mathbf{4 8}$ multiple choice items. The raw scores are converted to 80 point scale scores which correspond to each grade level and the scale scores are preceded by the grade level, third grade would range from 300 to 380 . Scale scores provide information related to the location of student achievement along the performance levels of novice, apprentice, proficient, and distinguished. The reading and mathematics area scales for each grade level were developed so a score of 40 represent a proficient performance level at every grade. A scale score of 340 and higher represents a student score which is at or above the proficient level (Kentucky Department of Education, 2010).

The KCCT is taken by students in grades three through eight, and 10 through 11 in the spring of each school year. Grade 12 students take an ondemand writing test in the fall of the same year. Third-grade students are 
assessed only in reading and mathematics. Science and social studies assessments are added to the test beginning in grade four (Kentucky Department of Education, 2010).

The NCLB Act mandates and the high stakes accountability, which is associated with the NCLB as well as individual state laws and sanctions, has generated a focus on measuring the effectiveness of teaching and the impact on student learning. There continues to be much interest in determining which teachers are more effective than others. If the factors contributing to the effectiveness could be identified, then that information could potentially be utilized to build a quality teaching workforce who exhibited those factors. A historical problem has been the difficulty in determining the teacher effects while separating out other factors which may relate to student learning, such as parental income and ethnicity. The data related to these factors are more difficult to manipulate (McCaffrey, Lockwood, Koretz, \& Hamilton, 2003).

Bealmear (2006) studied the self-efficacy between NBCTs and teachers considered Highly Qualified (HQ), according to NCLB, in the effective teaching of middle and high school African-American students who were receiving special education services (Bealmear, 2006). This researcher examined best instructional practices utilized by NBCTs and teachers of special needs students in the context of the classroom culture. The results of this study indicated that the Highly Qualified teachers demonstrated a higher score in the efficacy areas than the NBCTs. The NBCTs "did not perceive they possess as much affirmation 
of diversity or understanding about special education in this study" (Bealmear, p.2006, p. 99).

Over the past several years, value-added methodology (VAM), particularly the Tennessee Value-added Assessment System (TVAAS) developed by William Sanders has been widely used in assessing the effectiveness of teachers. The TVAAS is a very complex statistical model known as mixed models. This is basically a growth model which measures the increase in student performance from an initial test score assigned to each student at the beginning of a school year and test scores from an assessment administered at the end of the same school year (Sanders \& Horn, 1998). Value-added models have the potential to improve upon assessment systems because current models "provide an illustration of beginning points, clarify some possibilities of use, and exhibit the challenges of implementation around linking teacher and student data" (Noell \& Kowalski, 2010). However, there are questions related to the ability of this model to truly measure the effectiveness of teachers.

For more than a decade the National Board Certification process has received recognition as a viable system in the identification of quality teachers. Researchers continue to question whether or not this certification truly distinguishes those teachers who actually improve student learning.

\section{Purpose of the Study}

The purpose of this study was to investigate the relationship between student achievement in reading and mathematics and National Board Certified Teachers (NBCTs). Several researchers have investigated the link between 
NBCTs and raising the achievement of students; however, as previously noted, these studies were conducted in states other than Kentucky. Consequently, this study may help determine the relationship between Kentucky teachers who hold National Board Certification and the achievement of their students in reading and mathematics. The findings provided further information relative to the impact of NBCTs on student achievement across the country. This insight may then provide direction for resource allocation, professional development opportunities, and other responses.

While this study's main focus was to determine the impact of NBCT's on the reading and mathematics achievement of their students, the investigator anticipates that the findings and methodologies employed in this study might contribute to previous research which looks at the relationship between learning and teaching.

This quantitative study compared the $2009 \mathrm{KCCT}$ reading and mathematics assessment results of students in the third grade who were assigned to NBCTs, with third-grade students assigned to teachers who did not have NBPTS Certification. Third-grade students were targeted for this study because students exit the primary program in Kentucky at the completion of third grade. The expectation is that all students are prepared to enter the intermediate grades when they exit primary (performing at or above grade level in reading and mathematics). Reading and mathematics scores were utilized because those content areas serve as the focus of the No Child Left Behind's Adequate Yearly 
Progress accountability. Results from the 2009 state assessment were used because these are most recent available data.

The study (a) reviews the No Child Left Behind mandates associated with Adequate Yearly Progress for students in the areas of reading and mathematics;

(b) provides a description of the established standards for National Board Certification; (c) identifies the $2009 \mathrm{KCCT}$ reading and mathematics scores of nearly 413 students assigned to NBCTs and 398 students not receiving instruction from NBCTs; (d) discusses potential implications for students who at risk due to socioeconomic status; and (e) suggests implications regarding the merits of Kentucky teachers participating in the NBPTS training and certification in light of the potential relationship of this study to the students' achievement in reading and mathematics.

\section{Significance of This Study}

This study is important as it addresses the accountability of schools to meet AYP in reading and mathematics on Kentucky's state assessment, a high stakes accountability factor. Further, it examines the effect of teachers who have met standards of quality (as established by the National Board for Professional Teaching Standards) on student achievement as measured by third-grade students' performance on the KCCT in reading and mathematics. Kentucky's legislators have provided significant funding to support teachers in their pursuit of National Board certification over the past twelve years. This financial support includes a mandated and state funded $\$ 2,000$ salary supplement for NBCTs for the ten years the certification is valid, and a stipend for mentors for each 
candidate (the mentors must be NBCTs). Funding has been available to compensate the reimbursement of the cost of substitute teachers for five days. This provided National Board candidates release time to work on portfolio entries and to prepare for the assessment center exercises. Teachers worked toward National Board Certification on a voluntary basis over the course of several months. Kentucky's NBCTs receive $75 \%$ reimbursement of their out-of-pocket expenses for application fees.

The results of this study were intended to provide much needed data to either support the continuation of state funding for National Board candidates or to establish recommendations for the revision of the current legislation related to funding and assistance for the National Board Certification process. The national and state accountability mandates for increasing student performance outcomes on the state assessments have important implications for quality instruction, its potential link to NBCTs, resource allocation for professional development opportunities, and career advancement of teachers in school districts.

Educators make great efforts to identify professional development opportunities, successful instructional practices, and indicators of quality teaching as a means to increase student performance and to meet the AYP goals. The results of this study have been intended to suggest considerations for professional learning opportunities related to the National Board Certification process.

If educators and policy makers are truly serious about addressing the disparity in student achievement, there must be a conscious consideration of 
equity, achievement levels, and accountability by administrators when making decisions about teacher assignments. There must also be an emphasis on research-based professional pedagogy in promoting effective instructional strategies for assisting all students in comprehension of content. Professional development should include a focus on addressing the barriers to learning for low-achieving and at-risk students, such as tracking, low teacher expectations, and failure to effectively differentiate instruction.

With the revision of the Kentucky Teacher Internship Program (KTIP) to reflect beginning teachers' skills in demonstrating the NBPTS Core Propositions, this study may provide insight into teacher preparation and pre-service programs. University programs and student teaching experiences might benefit from input from NBCTs.

The study's findings might be useful to administrators as they hire and make teacher assignments within the demographics of their student population. The results of this study could also serve as a resource in specific training and retention of "quality teachers" to ensure that all students achieve at proficient levels.

\section{Research Questions}

This study focused on three broad research areas: (1) accountability for learning (according to the No Child Left Behind federal legislation); (2) teacher quality (based on National Board for Professional Teaching Standards); and

(3) state assessment (Kentucky Core Content Tests) results in reading and mathematics for third grade students. These areas are critical in identifying the 
competencies and skills necessary in educating student populations regardless of their prior achievement levels. They also are closely coupled with potential professional learning opportunities.

This quantitative study addressed the following research questions:

1. Is there a statistically significant difference in achievement in reading between end of primary students assigned to National Board Certified Teachers (NBCTs) and teachers who are not NBCTs?

2. Is there a statistically significant difference in achievement in mathematics between end of primary students assigned to NBCTs and teachers who are not NBCTs?

3. For NBCTs, does number of years in which they have been National Board Certified have a statistically significant positive correlation with end of primary student performance in reading and mathematics?

\section{Limitations of the Study}

There were limitations to this study. The changes in the state assessment due to Senate Bill 1 limited the student achievement data to one test score in reading and mathematics. Although Kentucky ranks number twelve in the number of NBCTs on a national level, there were 171 NBCTs listed as primary teachers. From the list of these 42 NBCTs, the investigator identified only 26 who were primary classroom teachers who taught both reading and mathematics and 20 of these teachers participated in the study.

VAM or TVAAS methods could not be utilized for this study or on a statewide basis in Kentucky. The existing assessment and accountability system 
does not include an annual norm referenced assessment to measure achievement growth and cannot provide the necessary data for conducting VAM studies. "Without the ability to link teacher and student data, states will not be able to return important information to teacher preparation programs" (Noell \& Kowalski, 2010).

\section{Definitions}

Adequate Yearly Progress (AYP): Schools and districts must meet annual target goals established for reading and mathematics or face sanctions at the state and federal levels (NCLB, 2002).

Criterion Referenced Test (CRT): Specific criterion leveled skills which are specified as indicating an acceptable level of mastery or proficiency (Kentucky Department of Education, 2010).

Cut Score: Sometimes called a cut point, because it is the actual score that indicates the dividing line between performance levels (Kentucky Department of Education, 2010).

Kentucky Core Content Test (KCCT): Criterion Referenced Test consisting of a combination of open response and multiple choice items (Kentucky Department of Education, 2010)

National Board Certified Teachers (NBCTs): Teachers who have successfully met the standards established for certification by the National Board for Professional Teaching Standards (NBPTS, 2009) 
Norm Referenced Test (NRT): A normative comparison in which the results must be compared to appropriate peer groups, such as other third-grade students (Kentucky Department of Education, 2010)

Senate Bill 1: passed by the Kentucky General Assembly in 2009 and brought about a new era for assessment and accountability in the public schools (Kentucky Department of Education, 2010)

\section{Conceptual Framework}

This study was an investigation of the student achievement results of two teacher groups: NBCTs and a control group of teachers. The control group of teachers was either from the same school, same district, or an adjacent district as their comparison NBCT. NBCTs are considered exemplars of quality teaching through their certification with the National Board of Professional Teaching Standards. Their certification reflects satisfactory demonstration of the ability to integrate learning, assessments, and research-based instructional strategies. The standards also require the National Board candidates to reflect on their teaching practices as well as their contribution to the education profession. Each candidate must also provide exemplary evidence of demonstrated competencies for every standard.

According to Darling-Hammond and Ducommun (2010), "Teacher quality might be thought of as the bundle of personal traits, skills, and understandings an individual brings to teaching" (Darling-Hammond \& Ducommun, 2010, p. 2). The researchers recommends specific qualities linked to what teachers should be and 
do. These qualities include strong intelligence, strong knowledge of content, competencies in content pedagogy, strong knowledge of how students learn expertise in adjusting instruction to meet the needs of individual students, and collaboration with others to support learning. She concludes that each of these qualities is addressed through the NBPTS certification process (DarlingHammond \& Ducommun, 2010).

The NBPTS are based upon five core propositions. These propositions focus on the commitment of teachers to their students and student learning, content knowledge and pedagogical skills, the management and monitoring of student achievement, continued professional growth, and collaboration with others to enhance learning experiences (NBPTS, 2009).

The Kentucky Internship Program (KTIP), required for certification of new teachers has designed the program to parallel the National Board Certification process. The KTIP standards are the same; however, the demonstrators reflect competencies and expectations of new teachers. These demonstrators are on a continuum aligned with exemplars of NBPTS Certification. The designers of KTIP were intentional in the design of the program to establish a direct connection to professional growth in quality teaching and successful demonstration of the NBPTS (KEPSB, 2009).

The NCLB language is clear in expressing that teacher quality is critical to student achievement. Each of the 50 states has engaged in national discussions related to the definition of "highly qualified teachers" as referenced in the NCLB Act. This law states that a highly qualified teacher holds a minimum of a 
bachelor's degree, fully certified and licensed by the state, and has demonstrated competency in the core academic subjects he or she is assigned to teach (U. S. Department of Education, 2002).

Chapter Two of this study addresses the pertinent literature related to the areas of quality teaching research, Kentucky's interim Core Content Test, the revised state assessments related to Senate Bill 1, National Board for Professional Teaching Standards studies, and the No Child Left Behind Act. The chapter also includes quantitative data methods to support this study and to establish a statistical framework for the analysis of data. 


\section{CHAPTER II \\ REVIEW OF LITERATURE \\ Student Achievement Accountability}

The Kentucky Education Reform Act (KERA) was passed into law in 1990 by the General Assembly as House Bill 940 . This monumental legislation was a bold plan for improving the state's public education system. The impact of KERA brought about broad changes in what students should know and be disposed to do and an assessment system which held school districts accountable for student achievement results. The mandates of KERA propelled the Commonwealth of Kentucky to a high-stakes accountability education model which rewarded school districts that met their annual achievement goals and sanctioned those districts that did not (Legislative Research Commission, 1994).

The original assessment system outlined in KERA was comprised of several parts. Students took a criterion-referenced test addressing reading; mathematics; science; social studies; on-demand writing; arts and humanities; and practical living and vocational studies. Student writing was evaluated through a portfolio, a collection of written work. The assessment also included performance assessments which students completed alone or as part of a group (Legislative Research Commission, 1994). 
Since 1990, legislators have made adjustments and revisions to the curriculum and the state assessment accountability system. The performance assessments were eliminated after the first biennium of the implementation of KERA. By the mid 1990s, the legislators added multiple choice items to the assessment in order to include a norm-referenced component to the system and reduced the number of written samples for the writing portfolio from six to four. The arts and humanities and the practical living and vocational studies assessments were shortened as well. The accountability model was redesigned so that all schools and districts were to reach a score of one hundred by the year 2014 (Kentucky Department of Education, 2010).

In 2001, the No Child Left Behind Act (NCLB) became a federal law, and according to NCLB, all students have the right to a quality education and to high level achievement. The law was established to ensure that the achievement gaps for students with disabilities, those eligible for free lunch, and various ethnicities were not statistically significant. The law further established increased accountability for graduation rates (United States Department of Education, 2002).

Schools and school districts are held accountable for reaching annual targets for proficiency in reading and math. Performance in relation to these targets determines the school's and the district's Adequate Yearly Progress (AYP). Schools must meet or exceed the annual targets in order to meet the required AYP (United States Department of Education, 2002). 
The NCLB Act (2001) requires annual assessments in reading and mathematics for students in third through eighth grade. Schools are accountable for reducing the number of students scoring at the novice level, increasing student achievement levels and narrowing the achievement gap between the scores of all students and other student subpopulations (students with disabilities, students eligible for free or reduced lunch, and students of other ethnic groups). Schools not meeting even one of the targeted sub-goals, benchmarks for the students represented from the subpopulations, are categorized as not meeting AYP goals (United States Department of Education, 2002).

To address NCLB accountability mandates, the Kentucky General Assembly revised the assessment and accountability system once again to define AYP determinations and be in compliance with NCLB). Students were assessed on Kentucky's Core Content Test (KCCT) in reading and mathematics each school year during the spring. The results of the KCCT are used to determine whether or not a school and district have met the AYP goals. The intent of the Kentucky legislation is for all students who are enrolled in grades three through twelve participate in assessments through the KCCT. This is accomplished through a standardized test administration for most students. Students with disabilities are assessed or with accommodations or through the Alternate Assessment program (Kentucky Department of Education, 2010).

When a school in Kentucky fails to meet AYP for two consecutive years, the district and school are identified as Tier 1 assistance schools, and the staff 
must revise their school improvement plans to address the areas linked to their AYP. A school's plan for improvement must include ways to strengthen instruction (including research-based professional development activities) and address the causes of the failure to meet AYP (Kentucky Department of Education, 2010).

Parents of students in Title 1 schools in need of improvement have the option to transfer to another public school in the district which is not in school improvement status. Parents of students in Title I schools identified for their second year of school improvement are eligible to receive supplemental services for their children. Title 1 schools are designated as such when the student population of the school is comprised of at least $35 \%$ of students who are eligible for the federal free or reduced lunch program (United States Department of Education, 2002).

The Kentucky General Assembly passed into law Senate Bill 1 in 2008 which significantly changed the state's curriculum standards to common core standards adopted by 47 other states and three territories. This change will allow Kentucky's student achievement results to be compared to students in other states based on a common curriculum. The Kentucky Core Content Test would be modified to reflect an interim assessment period between 2009 and 2011 . The interim period would include a criterion referenced test in 2009 and would add a norm-referenced test to be administered in the spring of 2010 . The results of the norm-referenced test will then be utilized as a baseline for longitudinal student data for 2011 and beyond. However, the state assessment in 2009 was 
limited to a criterion referenced test. A norm-reference assessment was delayed until 2010. But the accountability for narrowing the achievement gap and increasing student scores continues during the interim period (Kentucky Department of Education, 2010).

In summary, the mandates established by the Federal NCLB are clear: it is imperative that all students should learn at high levels based on state and federal accountability. Further, school districts must also demonstrate continuous improvement in closing the achievement gap. Kentucky's accountability for school districts is moving toward a longitudinal data system for measuring student achievement growth. All children deserve to achieve academically at high levels and to be afforded a quality education (United States Department of Education, 2002).

\section{Quality Teaching}

The National Commission on Teaching and America's Future (1997) examined the nation's progress toward the goal of high-quality teaching in every classroom in every community. Among the Commission's recommendations are:

1. Standards for teachers should be linked to standards for students starting with agreement on what teachers should specifically know and be able to do in helping students successfully meet the requirements of the new standards.

2. Revise teacher preparation programs and professional development opportunities by the following: 
- Reorganize teacher education programs and professional development sessions around standards for teachers and students;

- Create stable, high-quality sources of professional development, then allocate $1 \%$ of state and local spending to support them, along with additional matching funds to school districts;

- Embed professional development in teachers' daily work through joint planning study groups, peer coaching, and research.

3. Put qualified teachers in every classroom.

4. Encourage and reward knowledge and skill through the following:

- Develop a career continuum and compensation systems that reward knowledge and skill;

- Enact incentives for National Board Certification.

(National Commission on Teaching and America's Future, 1997, p. 5).

The Commission concluded that the issue of teacher quality must be addressed systemically. "More parents should demand that their children be taught by well-prepared and qualified teachers" (National Commission on Teaching and America's Future, 1997, p. 3). Other suggestions referenced the need for legislators to focus on quality teaching and for administrators to ensure that best instructional practices were embedded in professional learning. "More 
teachers need to insist that their occupation evolve into a true professionsupported by access to the knowledge needed to help students" (National Commission on Teaching and America's Future, 1997, p. 4).

Darling-Hammond and McLaughlin (2000) noted the rising evidence that teachers who were well prepared were consistently more effective in the classroom. The researchers conducted a study on teacher effectiveness using data accessed from a survey related to policies from fifty states, the 1993-94 Schools and Staffing Surveys (SASS), the analysis of state case studies, and the National Assessment of Educational Progress (NAEP).

This study focused on school inputs and teacher qualifications and how those were related to achievement levels of students. The quantitative and qualitative analyses determined that licensure and teacher preparation may be indicators of the effectiveness of teachers based upon student learning outcomes. They linked teacher effectiveness to state policies in the areas of certification, pre-service training, years of experience, and professional development experiences. They concluded that student achievement, including performance on assessments, is dependent upon teacher preparation, pedagogical capacities, and on what teachers know and are disposed to do in their classrooms (Darling-Hammond \& McLaughlin, 2000).

The researchers also determined that teachers often need assistance in translating theory into practice through job embedded professional development. These professional growth opportunities are most beneficial when related to the 
professional development activity being implemented in the classroom (DarlingHammond \& McLaughlin, 2000).

Sanders and Rivers (1996) further addressed quality teaching through the development of the value-added assessment model (VAM) data analysis process. The VAM is a robust statistical model which measures achievement through growth over time with longitudinal student assessment data. The intended purpose of VAM models is to examine what change in achievement of students over a specific time period is directly attributed to instruction by the teachers, while controlling for factors which may differ among classrooms and schools.

Sanders, a statistician at the University of Tennessee, adapted the VAM in developing the process known as the Tennessee Value-Added Assessment System (TVAS). The TVAS became an integral part of the Tennessee Educational Improvement Act of 1993 and is still in use in that state and as a statistical model of many other states today. The main purpose of the TVAS data analysis is to measure the effect of the teacher on the increase in student achievement when adjustments are statistically made to address other factors related to non-school attributes, such as family income and parental education levels (Sanders \& Rivers, 1996).

These researchers disaggregated student data on state assessments in Tennessee through a statistically robust process. They defined teacher effectiveness by comparisons of students' test results each school year with their test results from the previous grade, which was used as a baseline. Teachers 
were labeled most effective if their students made significant gains on the state assessments compared to the baseline score. They grouped the teachers in quintiles ranging from highest to lowest based upon the effectiveness of the teacher. They then recorded estimates of expected gains over a period of one year by students on the Tennessee's state standardized test when assigned to various teachers (Sanders \& Rivers, 1996).

Over the three-year study, Sanders and Rivers (1996) concluded that high performing students who had received instruction from the most effective teachers made average gains of 25 points on the Tennessee state assessment. The gains of high performing students who were assigned to ineffective teachers were just two points. Sanders and Rivers (1996) found that the difference in achievement for these students could be a full achievement level in one school year. In addition, they further noted that low-achieving students assigned to effective teachers made gains of 50 points on the state assessment yet the gains of low achieving students assigned to ineffective teachers was only 14 points in comparison.

Sanders and Rivers (1996) unveiled the effects of a sequence of teachers. Students who had effective teachers for two or more consecutive years experienced a cumulative impact. But the most alarming discovery the researchers made was that the results for students who had received instruction from the least effective teachers over a period of two or more consecutive years were also additive and cumulative. In other words, the "residual effects of poor teaching are evident in student performance results for a minimum of three to five 
years" (Sanders \& Rivers, 1996, p. 8). These researchers argued that the goal for students should be that the gain for each child be approximately the same amount and that less than that amount is unethical (Sanders \& Rivers, 1998).

However, Haycock (2001), warned of the dangers related to the work of Sanders and Rivers in the notion that if all students grow from where they are, the gap will still be evident. The author adds that her research has concluded that minority and poor students could achieve at very similar high levels as their peers if their instruction was focused on those same high levels. She has documented that there is a "clear relationship between low standards, low-level curriculum, undereducated teachers, and poor results" (Haycock, 2001, p. 2).

Haycock (2001) agrees with Sanders and Horn (1998) that by assigning the best teachers to low-performing students, "there is persuasive evidence to suggest that we could entirely close the achievement gap" (Haycock, 2001, p. 7). She reports that schools and teachers can make a difference; however, Haycock maintains that there has been no consensus on a method of measuring the variables related to quality teaching and the effect on students in the past. She reported that a national movement is emerging to use student achievement data for identifying the effectiveness of teachers; and that those effective teachers equate to student success (Haycock, 2001).

Professional development related to meeting the instructional needs of diverse populations is a high priority, according to Haycock (2001). The researcher states that deep knowledge of content is essential for effective teaching of students of all ability levels (Haycock, 2001). Haycock related 
student achievement and quality teaching by suggesting that if education leaders wish to accomplish a goal of this nature in the near future, they would be more successful if their focus was on quality. This would mean quality in preparing teachers, hiring, recruitment, assignment, and embedded professional development" (Haycock, 2001). She notes that the efforts of the National Board for Professional Teaching Standards might advance the comprehension of developing and assessing the knowledge and skills required for quality teaching (Haycock, 2001).

Noell and Kowalski (2010) investigated teacher effectiveness and the need for efficient statewide teacher and student data systems. They suggest that student data would include grade level, gender, Title 1 status, economic status, ethnicity, attendance, and performance on various state and national assessments. The American Association of Colleges for Teacher Education (AACTE) defines teacher data as a listing of college major, current teaching assignment, gender, ethnicity, retention, certification areas, graduate degrees, and certification exam scores for each teacher. The researchers reference the importance of reliable data systems in tracking longitudinal student outcomes to teachers (Noell \& Kowalski, 2010).

As states strive to find methods to adequately measure the effectiveness of teachers in fair, reliable, and valid ways, data systems must have the capacity to yield data which can enhance the evaluation process. The researchers conclude that linking teacher and student data is critical to tracing teacher effectiveness, designing appropriate professional development plans, and to 
monitor student progress. They advise that if states wish to increase the number of effective teachers, they will need access to better information. The researchers also recommend that teachers receive assessment data on individual students in a timely manner and that states develop value-added summaries as teacher impact reports (Noell \& Kowalski, 2010).

Sir Michael Barber served as the head of Prime Minister Tony Blair's Delivery Unit from 2001-2005; and, during that time, he made significant progress in elevating education reform in Great Britain (Barber, 2008). Barber conducted research on high performing education systems in several countries prior to developing and implementing the revised education program in Great Britain. He employed the VAM for assessing teacher effectiveness and found that "consistent quality of teaching is by far the most important factor driving performance and is missing in most systems" (Barber 2008, p.168). He devoted much time and effort in recruiting students from universities who were in the top $5 \%$ of their class due to his findings from researching high performing education nations and reported that great educational systems must make increased efforts in attracting great individuals into teaching (Barber, 2008).

Barber (2008) followed the progress of students who were at the same performance level of the 50th percentile at age eight through the VAM. These students who were assigned to high performing teachers (among the top $20 \%$ of teachers) were at the 90th percentile by age 11 , while their peers assigned to low performing teachers (among the bottom 20\% of teachers) regressed to the $37^{\text {th }}$ percentile at age 11. He concluded that improving instruction was the way to 
improve outcomes and that "the quality of an education system cannot exceed the quality of its teachers" (Barber, 2008, p. 282).

\section{Assessing Quality Teaching}

Emerging bodies of research identify teacher quality as the single-most significant determinant of student performance in our schools. In promoting the notion of quality teaching, "It is not sufficient just to focus at the front end on teacher preparation and at the back end on recognizing more-experienced, accomplished teachers," says Odden and Kelly (1997) of the University of Wisconsin-Madison. A paradigm shift of this nature requires a professional system quite different from the typical human-resources systems (Odden \& Kelly, 1997). These researchers defined the professional system as a process of five steps. First, standards should be developed which represent quality teaching practice. Second, those standards should be shared with multiple professional educators who have demonstrated expertise in good instruction. Third, prepare a plan and provide for ongoing professional development opportunities for teachers which are geared to high practice levels. Fourth, external assessments required for new and experienced teachers are connected with internal assessments which would create sequential bases for ongoing knowledge and competencies development throughout the teacher's career. The final step of the process is to link additional compensation to teachers who continue the enhancement of their competencies and skills (Odden \& Kelly, 1997).

A systemic approach such as this or a framework for professional growth of quality teachers would radically change and strengthen school and district 
human resources system, which would significantly contribute to a process for quality assurance in the preparedness of new teachers and assisting in the continuation of professional growth throughout their careers. The researchers recommended that National Board Certification should be a valid measure for the purposes of additional professional compensation (Odden \& Kelly, 1997).

A framework for professional practice should be based on the highest standards, which reflect the complexity of teaching and best practices for instruction according to Danielson (1996). This framework would provide direction for beginning teachers and guidance for experienced and accomplished teachers. She studied the competencies and skills which were observed in classrooms of teachers identified by their students' achievement gains and developed a framework based upon the observations and comprehensive standards describing good teaching practice. Her framework is the basis for ongoing professional development for teachers as well as the performance evaluation for teachers. This framework establishes 22 different teaching components organized into four teaching domains: planning, instruction, assessment, and reflection. Using the framework as a reference for quality teaching, teachers and evaluators can design a professional development plan, which advances their expertise to the next level of performance (Danielson, 1996).

Danielson's framework served as a basis for establishing demonstrators recognized by the Carnegie Task Force on Teaching as a Profession (Carnegie Task Force on Teaching as a Profession, 1986). The framework is also 
referenced in the development of the National Board for Professional Teaching Standards (Danielson, 1996; Carnegie Task Force on Teaching as a Profession, 1986; NBPTS, 2007, www.nbpts.org ).

Guskey (2000) studied professional development and notes that professionals must stay abreast of new knowledge related to their fields and "use it to continually refine their conceptual and craft skills" (Guskey, 2000, p. 82). Guskey defines the characteristics of professional development as an intentional, ongoing, and systemic process. He identified the critical levels of professional development as reactions by the participants, new learning of the participants, the organizational support for the change, the participant's ability to implement the new knowledge, and the impact on student learning (Guskey, 2000).

Guskey (2000) also suggested a model for growth in pedagogical competencies for quality teaching through a progression of stages after a meaningful professional development "change in classroom practices, change in student learning, and change in teachers' attitudes and beliefs" (Guskey, 2000, p. 139). This progression clearly links teacher learning and student achievement.

\section{National Board for Professional Teaching Standards (NBPTS)}

Nationally known professional organizations have proposed standards both for pre-service teachers and licensed teachers. One of the most well-known organizations to address teacher standards for experienced teachers was the National Board for Professional Teaching Standards (NBPTS, 2009, www.nbpts.org ).

In 1986, the Carnegie Task Force on Teaching as a Profession issued $A$ 
Nation Prepared: Teachers for the $21^{\text {st }}$ Century, and its leading recommendation called for the establishment of a National Board for Professional Teaching Standards (NBPTS). The committee recommended the Danielson (1996) framework as a reference for the standards and stated, "The key to success lies in creating a profession equal to the task" and urged the teaching profession to set standards and to certify teachers who meet those standards (Carnegie Task Force on Teaching as a Profession, 1986, p. 5).

In 1987, the NBPTS was created. NBPTS is an independent, nonprofit, nonpartisan organization governed by a 63-member board of directors, of whom at least $51 \%$ must be practicing classroom teachers. Additional members include school administrators, school board members, politicians, higher education officials, teacher union/association leaders, and members of the private sector. The main focus of the NBPTS was to develop standards for what they have determined effective teachers should know and do and to design and implement a system for assessing teachers nationwide to determine if they have met those standards (NBPTS, 2009, www.nbpts.org ).

Based upon a central policy statement "What Teachers Should Know and Be Able to Do," the NBPTS has established advanced standards in more than thirty certificate fields. "NBPTS was created with the goal of determining whether practitioners know their subjects and how to teach them effectively to diverse learners-teaching's double helix" (Center for Teaching Quality, 2005, p. 7).

Teachers who apply for National Board Certification are expected to demonstrate their professional skills, knowledge, and accomplishments. The 
NBPTS content-related standards are derived through professional consensus and are based on five core propositions. These core propositions focus on the commitment to students and student learning, knowledge of content and pedagogy, continuous monitoring of student learning, reflection, and working collaboratively in professional learning communities (NBPTS, 2009 www.nbpts.org). Darling-Hammond and Ducommun (2010) researched a method for supporting quality teaching. The researchers outline approaches for identifying teacher effectiveness and recommend a framework for the identification and development of effective teachers and quality teaching. They suggest that quality teaching includes the ability to utilize effective practices which lead to high levels of student learning (Darling-Hammond \& Ducommun, 2010).

These researchers define qualities of an effective teacher to include strong intelligence, the ability to explain ideas clearly, heavy content knowledge, a wide range of pedagogical skills, and adaptive expertise in responding to the needs of individual students. "All of these qualities are embodied in the standards adopted by the National Board for Professional Teaching Standards" (Darling-Hammond \& Ducommun, 2010, p. 2). They further suggest that if the access to these experienced, accomplished, and well-prepared teachers was a more equalized process, the result would be a positive impact on narrowing the achievement gap.

The authors noted that a number of districts and states focus on National Board Certification for use as a basis for professional compensation efforts and 
other forms of recognition, such as serving as a lead teacher or mentor. They also believe that the VAM is important in acknowledging the contributions of teachers to their students' progress and in evaluating instructional methods and programs (Darling-Hammond \& Ducommun, 2010).

The researchers recognize the state and federal mandates related to all students learning at high levels and the need for sweeping changes in the preparation, development, and support of teachers. This would include new ways to develop, evaluate, and recognize effective teaching throughout the career of teachers. They also suggest policy changes in pre-service programs, licensing, tenure, and appropriate professional development (Darling-Hammond \& Ducommun, 2010).

\section{NBPTS Studies}

According to the Center for Teaching Quality (CTQ), numerous studies have been conducted based on the relationship between the NBPTS and student achievement. An increasing number of studies focus on the student performance of NBCTs on achievement tests. Many studies have concluded that the students of NBCTs did indeed outperform students of non-NBCTs while others have suggested different conclusions (Vandevoort, Amrein-Bearsley, \& Berliner, 2004;

Goldhaber \& Anthony, 2004; Sanders, Ashton, \& Wright, 2005; Cavalluzzo, 2004; Cantrell, Fullerton, Kane, \& Staiger, 2008; Harris \& Sass, 2007; and Bealmear, 2006).

Currently, there is limited research on statewide data related to the achievement of students of NBCTs and there are no studies to date which are 
specific to Kentucky's NBCTs and student achievement. There are, however, similar studies which address the achievement levels of NBCTs in other states. There is also one Kentucky study specifically related to NBCTs and their impact on African American students with disabilities (Bealmear, 2006).

The National Research Council (NRC) of the National Academies released a report in 2008 which was based on an analysis of numerous studies and data related to the NBPTS. The committee developed a framework for evaluating 161 articles related to National Board Certification as an advancedlevel certification program. The NRC's analysis affirmed that National Board Certified Teachers (NBCTs) had a positive impact on the learning and the achievement of their students. They also recommended that National Board Certification was worthy of professional compensation for those teachers receiving this certification (National Research Council of the National Academies, 2008).

In their report, which was a meta-analysis of studies, they concluded that students who were taught by NBCTs made greater gains on state achievement tests than students who were taught by teachers who either had not attempted National Board Certification or teachers who were not successful in their pursuit of National Board Certification. They reported that "board certification is a signal that teachers with this credential are more effective than other teachers at positively impacting their students' test scores" (National Research Council of the National Academies, 2008, p. 20). 
Although numerous studies have related the link between National Board Certification and student achievement, the studies have been specific to states such as North Carolina, Florida, and California; and these studies are addressed in this section. This study is the first to focus on the impact of National Board Certification on student achievement in the Commonwealth of Kentucky, specifically the Kentucky Core Content Test (KCCT) in reading and mathematics. The results have been beneficial in exploring potential connections between the certification and reading and mathematics scores on the state assessment. The study could also has provided a basis for further research in Kentucky, including a cost benefit analysis of the state's National Board Certification initiative.

Vandevoort, Amrein-Beardsley, and Berliner (2004) focused on 35 NBCTs and their noncertified peers, all teaching third through sixth grade, and matched them to their students' scores on the Stanford Achievement Test (SAT) in mathematics, language arts, and reading. The study was conducted in Arizona and is based on one research question: What is the relationship between National Board Certification and student achievement as measured by performance on the Stanford Achievement Test? (Vandevoort, AmreinBeardsley, \& Berliner, 2004). The study is classified as an ex-post facto, causalcomparative research design because the researchers used four years of assessment data, in four grades, and three academic areas for $\mathbf{4 8}$ comparisons. The methodology included qualitative and quantitative data. The SAT-9 was used for the measurement of student achievement. The SAT- 9 is a normreferenced achievement test developed by Harcourt Educational Measurement. 
The Arizona Department of Education had established a longitudinal data set which included five years of data. The design of the study included one independent variable: National Board Certification status of the teachers. The treatment group included the students of the NBCTs and the control group included students of non-NBCTs (Vandevoort, Amrein-Beardsley, \& Berliner, 2004).

The dependent variable in the study was the difference in the pretest and posttest scores over one year for each of the students. The adjusted gain scores (AGS) of students assigned to NBCTs were compared to the AGS of the students of non-NBCTs. The qualitative data used in the study were collected from descriptive surveys and two observations. Information on the survey was related to opinions about assessments and whether or not the National Board Certification process had led to an improvement in their teaching.

The results of the study revealed that the students taught by NBCTs "surpassed students in the classrooms of non-certified teachers in almost three quarters of the comparisons" (Vandevoort, Amrein-Beardsley, \& Berliner, 2004, p. 22). Translating the effect size to grade equivalents indicated that gains registered by students taught by NBCTs scored over "one month greater than the gains made by the students of non-certified peer teachers" (Vandevoort, AmreinBeardsley, \& Berliner, 2004, p. 23). This was not determined to be a significant gain.

The researchers also raised the issue of potential false positives or false negatives. In other words, some ineffective teachers may be successfully 
certified due to their expertise in written discourse related to their instructional practices, while some very effective teachers may not be certified due to difficulty in articulating their instruction. One recommendation was that the NBPTS consider revising the certification process to include student achievement data (Vandevoort, Amrein-Beardsley, \& Berliner, 2004).

Some additional studies have provided empirical evidence related to the impact of NBCTs on student achievement. One of these studies was conducted by Goldhaber and Anthony (2004) in which they assessed the impact on elementary-level student achievement by NBCTs in North Carolina. The researchers utilized results from the state test which is a criterion-referenced test measuring the curriculum objectives listed in North Carolina's state course of study. They restricted their study to students in grades three, four, and five based on the premise that students in elementary school would be more likely to be assigned to one teacher. This factor would enable a direct link between student assessment results and their teachers (Goldhaber \& Anthony, 2004).

The researchers applied the value-added data analysis developed by Sanders (Sanders \& Rivers, 1996). They tested the student-level, value-added models using a multiple regression approach to determine if the "value added by NBCTs differs from that of unsuccessful NBCT candidates and non-applicant teachers" (Goldhaber \& Anthony, 2004, p. 4).

The main research questions utilized in this study were as follows:

1. Is NBPTS successfully identifying the more effective teachers among applicants? 
2. What are the measures of NBCT effectiveness? (Goldhaber \& Anthony, 2007, p. 4).

The researchers used "education production function methods to estimate the differences between teachers with differing involvement with NBPTS" (Goldhaber \& Anthony, 2004, p. 14). Among the functions used were teachers, school district, students, and school characteristics; and the dependent variable in the study were increased scores on reading and mathematics achievement tests (Goldhaber \& Anthony, 2004).

The findings of the study showed that NBCTs were more effective in comparison to non-NBCTs according to the gains in student achievement and 7 to 15 points higher than their counterparts on final exams. The "NBPTS effect" differed significantly by student type and grade level, however. The researchers also noted that NBCTs were less likely to be teaching "in schools with high percentages of poor, minority, and low-performing students" (Goldhaber \& Anthony, 2004, p. 27). However, the students of NBCTs demonstrated improvements in the end of the assessment by averaging $7 \%$ to $15 \%$ higher than their peers in classrooms with non-NBCTs (Goldhaber \& Anthony, 2004).

The researchers mention in the results section of their study that NBCTs tend to have some advantage in assignment selection. They found that NBCTs were more likely to be assigned to high performing schools in affluent neighborhoods and where the students were more capable than their peers. They did find that NBCTs were overall more effective with low-performing students, particularly those who are eligible for free or reduced lunch and 
minority students. However, they were less likely to be assigned to those students. They also found only a small correlation between student achievements when taught by an NBCT, but the correlation was statistically significant (Goldhaber \& Anthony, 2004).

One of the recommendations made by the researchers was to place NBCTs with struggling students. The researchers state in their paper that "Going through the NBPTS certification process does not appear to make a teacher more effective" (Goldhaber \& Anthony, 2004, p. 27). They imply that the National Board certification process may help to recognize teachers who were already effective, but the process does not positively impact teachers who were not high performing teachers prior to going through the certification process.

Norm referenced tests (NRTs) must be used in research which utilizes the VAM process, and there must be an effective data system which links students to their assigned teachers. Unfortunately, Kentucky has not included NRTs in the state assessment program to date and there is no data system for accessing a data set of student achievement results linked to their teacher of record. Lack of longitudinal data as well as a data system linking students and teachers in Kentucky are limitations for this model.

One of the largest studies, which examined the relationship between National Board Certification status and student achievement, was conducted by Sanders, Ashton, \& Wright (2005). The methodology of the study, a type of multi-level model based on the value-added analysis process was developed by Sanders (Sanders \& Rivers, 1998). The researchers took a similar approach as 
that of the Goldhaber and Anthony study (2004) and focused on end-of-grade test scores in reading and math in Wake County and Charlotte-Mecklenberg in North Carolina for students in grades three through eight. The researchers used more than 260,000 student records and included over 4,600 subject-teacheryear-grade combinations. Their study used three specific comparisons: NBCTs vs. teachers not pursuing the certification; NBCTs vs. those who plan to pursue certification; and NBCTs vs. those who were unsuccessful in their pursuit of certification (Sanders, Ashton, \& Wright, 2005).

The research questions for this study were as follows:

1. Do students of NBCTs make greater academic progress than students of teachers who have never attempted to attain National Board Certification?

2. Do students of NBCTs make greater academic progress than students of non-NBCTs who plan to attempt National Board Certification at some point in the future?

3. Do students of NBCTs make greater academic progress than students of teachers who attempted to attain National Board Certification, but who failed in their first attempt? (Sanders, Ashton, and Wright, 2005, p. 12).

The researchers stated that one of the most important findings was "the amount of variability among teachers with the same NBPTS Certification status is considerably larger than the differences between teachers of different status" (Sanders, Ashton, \& Wright, 2005). In other words, while NBCTs did not produce 
significant gains in overall student progress, there was significant improvement in some grades and in some subject areas. The difference in performance, however, was not statistically significant. There was no statistical difference for reading with students in grade eight, and no significant difference for mathematics for the random effects models (Sanders, Ashton, \& Wright, 2005).

The researchers also note that "if growth in student achievement is indeed an appropriate standard of teacher effectiveness, it follows that including student growth measures in the certification process would vastly improve its ability to identify quality teachers" (Sanders, Ashton, \& Wright, 2005). Currently, the National Board Certification process does not include evidence of improved student achievement.

Cavalluzzo (2004) provided an analysis of data similar to that of Goldhaber and Anthony (2004). She examined the relationship between 9th and 10th grade students' mathematics achievement and National Board Certified Teachers (NBCTs). This study, using a large data set from the Miami-Dade school district in Florida, was one of the few which focused specifically on the achievement of high school students. The researcher used the students' scores of all the district's 9th and 10th grade students on the Florida Comprehensive Assessment Test as a measure of achievement outcomes. The researcher observed 61 NBCTs and 101 applicants (Cavalluzzo, 2004).

Based upon a multivariate framework addressing the differences in school, student, and teacher attributes, this researcher analyzed evidence related to the following issues: 
- Whether students who had NBCTs as teachers had larger achievement gains in mathematics in the ninth and tenth grades than their counterparts without NBCTs as teachers;

- Whether students who had teachers who had failed the National Board Certification process, withdrew from this certification process, or were National Board candidates had larger achievement gains than their counterparts without these ties to National Board Certification;

- All else equal, how the size of student gains associated with several teacher quality indicators compare with one another;

- Whether the size of gains associated with NBC varies across different student populations. (Cavalluzzo, 2004, p. 8)

The researcher used a linear model that included teacher background levels, years of experience, graduate degree, and teachers teaching in certification area. Other variables were students' prior year scores and school attributes. The study's results indicated that the scores of students whose teachers were either NBCTs, or were pursuing National Board Certification, were significantly higher than students whose teachers were not NBCTs or in the process of certification (Cavalluzzo, 2004).

Cantrell, Fullerton, Kane, and Staiger (2008) noted two directions in examining teacher quality: using longitudinal assessment results to determine the impact of the teacher on student achievement directly (generating value-added estimates) and rating the performance of teachers through direct observations 
(Cantrell, Fullerton, Kane, \& Staiger, 2008). They recognized that the National Board Certification process follows the latter model. However, they used both approaches, the prior value-added assessment scores as well as observations, in identifying quality teachers in their study (Cantrell, Fullerton, Kane, \& Staiger, 2008).

The researchers investigated whether being assigned to an NBCT would improve student achievement. The researchers studied second through fifth grade students' data in mathematics and language arts. Each of the teachers in the study who had completed the application for National Board Certification and each of the applicants were randomly matched with a teacher who had not applied for certification. Ninety-nine pairs of teachers participated (Cantrell, Fullerton, Kane, \& Staiger, 2008).

This study was unique in that the researchers used the pass/fail score for certification as well as the numeric cut scores for the National Board applicants' reports as status variables. The authors concluded that there was no statistically significant difference in the language arts and mathematics scores between the students taught by teachers who were NBCTs and those who were applicants. The researchers did find that there was a significant difference between the students of these groups of teachers and those who had never applied for National Board Certification. The significance of this study is that the use of random assignments of teachers to students helped in controlling pre-existing differences among students assigned to teachers with National Board 
Certification and noncertified teachers (Cantrell, Fullerton, Kane, \& Staiger, 2008).

Bealmear (2006) conducted a study, in the context of Kentucky, on identifying effective instruction for African-American students with disabilities. The teachers in the study were either NBCTs or teachers who had a Master's degree but not National Board Certified. The study used a descriptive correlational design based upon a Likert-scale survey completed by a crosssection of 216 teachers, 103 of these teachers were NBCTs. The survey utilized in the study contained questions related to the perceptions, beliefs, classroom instruction, behaviors, and collective efficacy in teaching African-American students with disabilities.

The research questions in this study are:

1. What are the distinctions between NBCTs and non-NBCTs in the area of self efficacy for effectively providing instruction to African-American students with disabilities?

2. What may teachers learn from NBCTs and non-NBCTs who teach African-American students with disabilities?

3. What may be learned from NBCT's and non-NBCTs in determining best instructional practices for African-American students with disabilities and the culture of their classrooms? (Bealmear, 2006).

The perceptive survey contained diversity components and the respondents were asked to submit data related to their belief systems regarding diverse populations in classrooms and the extent to which they demonstrated 
acceptance toward those populations. The end of the survey addressed the competencies and skills in the area of students with disabilities receiving instruction in a collaborative setting.

The findings of the study revealed that the perception of the NBCTs did not indicate as much affirmation and knowledge of diversity or comprehension of special education. The control group of teachers had a higher score than the NBCTs on self-efficacy in instruction, parent involvement, and teacher levels.

This study advanced research in this area because limited research is available in the area of efficacy of NBCTs linked to the achievement of AfricanAmerican students. There is also limited published research related to efficacy of NBCTs assigned to African-American students with disabilities (Bealmear, 2006).

Harris and Sass (2007) considered the efficacy related to National Board Certification's effect on student achievement and the impact of NBCT's on the assessment scores of students in Florida on low- and high-stakes exams. Among the questions they focused on were the following:

1. Are teachers who become NBCTs more effective than other teachers?

2. Does National Board Certification provide a valid signal of a teacher's contribution to student achievement? (Harris \& Sass, 2007, p. 6).

This study used an extensive data set of over one million students based on results of all students in grades 3 through 10 in reading and mathematics on the Florida Comprehensive Assessment Test (FCAT), a norm-referenced test, over a five year period. The researchers used observations of over 33,000 
reading or language teachers, which included over 1,500 NBCTs (Harris \& Sass, 2007).

The authors found that, in contrast to previous studies, evidence that National Board Certification "provides a positive signal of a teacher's contribution to student achievement only in a few isolated cases" (Harris \& Sass, 2007, p. 24). The results showed that a significant positive result was evident in mathematics for those students who were taught by teachers who held National Board Certification and those who had teachers who were applicants and would be National Board Certified in the near future (Harris \& Sass, 2007).

In summary, the review of the literature in this chapter examined the mandates for student achievement accountability, the attributes of quality teaching, assessing effective teaching through the National Board Certification process, and the potential link between NBCTs and increased student achievement gains. Researchers of three of the largest sample studies, specifically Vandevoort et al., Goldhaber and Anthony, and Cavalluzzo, found evidence of a link between National Board Certification and student achievement through their studies (Vandevoort, Amrein-Beardsley, \& Berliner, 2004; Goldhaber \& Anthony, 2004; Cavalluzzo, 2004). Other studies, such as Sanders et al., Harris and Sass, and Bealmear, were not as conclusive in establishing this relationship (Sanders, Ashton, \& Wright, 2005; Harris \& Sass, 2007; and Bealmear, 2006).

Findings of various studies on the connection between NBCTs and student achievement based upon the results of state assessments have drawn 
criticism based on statistical and methodological issues such as: small samples lacking statistical significance; large samples resulting in a small statistical significance which is less convincing in differences; difficulty in factoring student attributes related to assignment to NBCTs; and inaccurate relationships between teacher assignment and student achievement data.

Overall, the studies on National Board Certification involved the utilization of a type of norm-referenced test (NRT) to represent student achievement; and, in some cases, the studies involved longitudinal data over an extended period of time. Kentucky's state assessment process has not included an NRT and no longitudinal student data existed at the time of this study. There is indeed a void of data related to the growing number of NBCTs in the Commonwealth of Kentucky and no studies at this point which address a possible link to student achievement.

The Kentucky Core Content Test (KCCT) is comprised of a series of open response questions and multiple choice items. This study provided student performance data related to a unique assessment system in a state where no published research has been conducted at this point related to the impact of National Board Certification on student achievement. This study also included NBCTs across the state, which includes rural, urban, suburban areas as well as a diverse population related to socioeconomic status.

Third-grade student assessment results in reading and mathematics from the 2009 KCCT was used for this study. During 2009, the cut score for the proficient level of student performance in reading and mathematics was 340 . 
The average scale score for third-grade students in reading was 341 and the average scale score for third-grade students in mathematics was 336 (Kentucky Department of Education, 2010).

Chapter Three, which follows, provides a discussion of the design and methodology of this study, research approval process, the data sources, and the procedures of the data analysis. There is also a review of the constructs related to the research questions. 


\section{CHAPTER III}

\section{METHOD}

The recurring theme throughout this study was quality teaching and the central role of teacher quality in student achievement. The purpose of the study was to determine if there were statistically significant differences in student achievement between students who were taught by teachers who were certified by the National Board for Professional Teaching Standards (NBPTS) and students who were taught by teachers without this certification. This chapter provides the details related to the methodology and design of the study in addressing the three research questions for this study.

Research Questions

1. Is there a statistically significant difference in achievement in reading between end of primary students assigned to National Board Certified Teachers (NBCTs) and teachers who are not NBCTs?

2. Is there a statistically significant difference in achievement in mathematics between end of primary students assigned to NBCTs and teachers who are not NBCTs?

3. For NBCTs, does number of years in which they have been National Board Certified have a statistically significant positive correlation with end of primary student performance in reading and mathematics? 


\section{Design of the Study}

The data analysis employed for this quantitative study could best be described as a multilevel model. The study addressed the relationship between National Board Certified Teachers (NBCTs) and non-NBCT's and their effect on third grade reading and mathematics scores on the 2009 Kentucky Core Content Test (KCCT). The $2009 \mathrm{KCCT}$ was completed in the spring of 2009, near the end of the school year. The researcher targeted third-grade students because students at that level would most likely be taught in a self contained classroom, assigned to one teacher for reading and mathematics instruction. This would enable a direct link between the students' assessment scores to their assigned teachers. Third grade is also the end of the primary grades, or a transition to the intermediate grades, starting in grade four, in Kentucky. One of the state education goals is that students exit primary reading at or above grade level.

The multilevel model analysis has emerged as a useful analytical technique in several fields through "critically examining the structure and function of collective constructs" (Creswell, 2008). The multilevel model is an effective tool in studying the relationships between an individual level dependent variable, such as reading and mathematics achievement, with an individual contextual expanding focus, such as gender, socioeconomic level, and ethnicity. This is done through nesting of the random coefficients and the contextual variables (Bickel, 2007).

Nesting refers to students being identified with a particular classroom; the classroom exists in a particular school; the school exists in a particular district. 
Educational settings post a challenge for statistical controls because the subjects within a set category do not cross group boundaries. Statistical models do not readily separate the teacher effects from other inside or outside school effects because the students assignments to classrooms are not typically made by random selection. Therefore the student characteristics may be correlated with the classrooms or schools (Bryk \& Raudenbush, 2002).

The researcher examined whether National Board Certification had a relationship with teacher impacts on the achievement of students. The observation units in the regression model were the third-grade students of the NBCTs and the comparison teachers who did not hold National Board Certification. The dependent variables for the analysis were the student's reading and mathematics scale scores on the 2009 Kentucky Core Content Test.

\section{Ethical Procedures}

In preparation for this study, the researcher applied to and received approval from the Institutional Review Board from the University of Louisville for permission to proceed with this study. The Institutional Review Board provides protection and ensures confidentiality for the subjects of the study. The researcher's dissertation co-chairperson, who is a faculty member at the University of Louisville, served as the principal investigator for the study in compliance with the institutional Review Board requirements. Both the co-chairperson of the dissertation and the researcher completed the training and certification process which is a prerequisite for conducting research and a requirement for Institutional Review Board approval. The study received an 
exempt status from the Institutional Review Board at the University of Louisville because the data analysis was from an existing data set of the 2009 Kentucky Core Content Test results for third-grade students. All participant information and the data collection used in the study will remain confidential.

\section{Sample}

The target research population was NBCTs who were certified as early childhood generalists or middle childhood generalists. A list of 171 NBCTs was provided to the researcher by staff members at the Kentucky Education Professional Standards Board. The list included the names of the NBCTs and the schools and districts where they were employed. In cross-referencing the names of the NBCTs on the list with the global email address listing of teachers in Kentucky, the researcher discovered that only 53 of these NBCTs were still classroom teachers. From these 53 NBCTs, only 26 were teaching third-grade students in a self contained classroom. Twenty of the 26 remaining NBCT's agreed to participate in the study. These NBCTs were located in urban, suburban, and rural areas of Kentucky; however, 15 of the NBCT's were located in the central section of Kentucky. The researcher utilized the Kentucky Education Professional Standards Board's website to access information related to the year each of the NBCTs received their certification and the number of years of teaching experience for each NBCT.

Staff members in the Assessment and Accountability Division at the Kentucky Department of Education and District Assessment Coordinators assisted with identifying 20 teachers who were not National Board Certified to 
serve as the comparison group. The study analyzed assessment results for 800 students.

\section{Data Collection}

Data for this study were gathered from two separate state organizations in Kentucky. The Kentucky Education Professional Standards Board (EPSB) furnished a list of National Board Certified Teachers (NBCTs) certified in the areas of Early or Middle Childhood Generalists. These certifications were targeted because they would encompass both reading and math, and they would address student achievement in third-grade classroom. The students targeted in these certification areas would be eight or nine years of age and this study focused on students in grade three, typically age eight or nine. This age group was compatible with students in third grade.

Staff members from the Assessment and Accountability Division of the Kentucky Department of Education (KDE) and the District Assessment Coordinators provided the reading and mathematics scores from the 2009 Kentucky Core Content Test (KCCT) for the students of NBCTs and the students of the comparison group by state student identification numbers. These numbers were provided by the NBCTs and district staff. Kentucky Department of Education does not have a data system which directly links students to their assigned teachers. In order to connect NBCTs identified for the study to their students' test results, the researcher mailed letters to each of the NBCTs with instructions for mailing their students' state identification numbers directly to the Kentucky Department of Education in a stamped and addressed envelope 
provided to these participants. No student names were shared, only the state student identification numbers of these students. Utilizing these identification numbers, the KDE staff and District Assessment Coordinators collected the KCCT reading and mathematics scores for students assigned to the NBCTs and those assigned to the comparison teachers, those without National Board Certification. The state student identification numbers also revealed other student demographic information. This information included race and ethnicity; eligibility for the federal free or reduced lunch program; and gender.

From this data set of KCCT scores, the Assessment and Accountability staff at KDE selected the comparison teachers for each of the NBCTs through a matching process. The first step for the matching process was to identify student scores from another third-grade classroom in the same school. If the NBCT's third-grade class was the only one in the school, they identified a third-grade class in another school in the same district. If there were only one school in the district with only one third-grade classroom, they selected a third-grade classroom in a school from a neighboring district to serve as the comparison. KDE staff and district personnel assisted in developing a list of student scores in reading and mathematics for each of the NBCTs, and a list of student scores of the comparison teachers for each of the NBCTs. The comparison teachers were numbered to match a specific NBCT.

\section{Data Analysis}

The first step in the data analysis for this study involved the application of statistical methodologies to control for class-level and student-level variables. 
Class level variables included the number of students eligible for free and reduced lunch and the percentage of students within ethnic groups. Student variables included ethnicity, gender, and free or reduced lunch eligibility.

The multilevel-model approach was an appropriate method for this quantitative research study which examined the complex potential relationship between quality teaching and student learning. This analysis was conducted by comparing the achievement of students from two groups of third-grade teachers. The first group consisted of 20 individuals who were National Board Certified Teachers (NBCTs). The second group consisted of 20 teachers without National Board certification.

To enhance the validity of comparisons, teachers from the two groups were matched. The procedure for matching included the identification by the EPSB of NBCTs in Kentucky who were certified as Middle Childhood Generalists, Early Childhood Generalists, or in Literacy (the appropriate certification for teachers of students in grade three). First, third-grade NBCTs were identified from the EPSB's list of NBCTs. Second, a matching teacher was identified by the Kentucky Department of Education. The latter was a third-grade non-NBCT teacher in the same school. If no teacher in the school could be used, a third-grade teacher in another elementary school in the same district was used. If the latter could not be identified, a non-NBCT teacher in an adjacent school district was used for the comparison teacher.

Scale scores of the third-grade students were used as the measure of achievement in third-grade reading and mathematics on the $2009 \mathrm{KCCT}$. The 
KCCT included open response (OR) items, which is a type of constructed response or multi-step assessment. The other assessment items were multiple choice, and these are scored correct or incorrect. The multiple-choice items provide coverage on the KCCT of a broad area of the content domain and assist with reliability of the student scores within a specific content area. The scores on the OR items and the multiple-choice items are.calculated into raw scores.

Scale scores are derived from weighted raw scores. Scale scores provide enhanced information related to the location of achievement within performance levels. The KCCT scores are calculated on 80-point scales which correspond to each grade level. In this case, scale scores would range from $300-380$ for thirdgrade students. A scale score of 340 or above would represent a proficient performance level in reading and mathematics for students in the third grade (Kentucky Department of Education, 2010).

The result of the data collection from teachers is illustrated in Table 1.

\section{Table 1}

Teachers Used in the Study

NBCT Teachers Non-NBCT Teachers ${ }^{a}$ (Matching Teachers)

1.

2.

20.
1.

2.

20. 
Matching teachers came from: (a) the same school, or (b) the same district, or (c) an adjacent district.

Variables Measured on Teachers

Each teacher was measured on several variables that had potential for influencing student achievement. The variables were these.

1. Teacher certification status $(\mathrm{NBCT}=1$, Non-NBCT $=0$ )

2. Years of NBCT certification (For NBCT teachers - number of years; for non-NBCT teachers, 0 )

3. Years experience as a teacher.

Variables Measured on Students

Students for each teacher were measured on the following variables.

1. Gender $($ Female $=1$, Male $=0)$

2. Ethnicity

3. Free or Reduced Price Lunch status ( Non-free $=0$, Reduced $=2$, and Free $=3$,

4. Kentucky Core Content Test (KCCT) result for Reading (scaled score)

5. Kentucky Core Content Test (KCCT) result for Mathematics (scaled score)

\section{Statistical Analysis}

For research questions 1 and 2, randomized block analysis of variance (ANOVA) was performed. The within group independent variable was teachercertification status. Dependent variables were student mean scores in reading and mathematics. 
In addition to ANOVA, research questions 1 and 2 were addressed with a repeated observations hierarchical linear model (HLM). For the latter, student variables were the level 1 variables and teacher-certification status and number of years teaching served were the level 2 variables.

To address research question 3, two Pearson correlation coefficients were calculated. The first of these used these variables: number of years of teaching experience and mean reading score of students taught by the teacher. The second one used these variables: number of years of teaching experience and mean mathematics score of students taught by the teacher.

\section{Limitations}

The study utilized a very small sample size of only 20 NBCTs, 20 teachers who were not NBCTs, and 811 student sets of scores. When conducting research on teacher effects, researchers need to complete the data collection in the context of a randomization experiment or within parameters where the researcher can control over the variation of sources. In other words, students would be randomly assigned to teachers and the researcher would control any sources of variance. Students might be preselected to ensure that the classrooms were homogenous in comparing student-achievement levels.

An important step in this type of variance control would be to assess all students in the study twice, once at the beginning of the year and again at the end of the year. This is the basic procedure for the value-added model (VAM) of data analysis (Sanders \& Rivers, 1996). The study was limited to only one 
reading and mathematics assessment score for each of the students and the students were not randomly assigned to the teachers.

\section{Conclusion}

The review of the research literature in Chapter Two overall indicates that the students of NBCTs tend to score higher on tests than students of teachers who did not hold National Board Certification. The research examined whether the 2009 KCCT reading and mathematics scores of third-grade students assigned to NBCTs differed from third-grade students assigned to teachers who were not NBCTs. According to the data analysis, there was no statistically significant difference in the students' test scores.

Research related to NBCTs and student achievement is somewhat limited and is relatively recent. This study may serve as a contribution to a larger research literature review as a recent addition to studies which were conducted 3 to 10 years ago. The researcher also believes that the study's findings may contribute to policy issues related to professional compensation and budget decisions.

\section{Definitions}

ANOVA-provides a statistical test of whether or not the means among two or more groups are equal, under the assumption that the sampled populations were normally distributed. It is a repeated observations hierarchical model (Bryk \& Raudenbush, 2002).

MANOVA-two group multivariate analysis of variance. MANOVA is used when . there are two or more dependent variables. It is used to identify interactions 
among dependent variables and among independent variables (Bryk \& Raudenbush, 2002).

ANCOVA - an analysis of covariance based on inclusion of supplementary variables or covariates into the model. This analysis allows researchers to account for intergroup variation associated with the covariates and not the "treatment" itself (Bryk \& Raudenbush, 2002).

Fixed effects-measures of factors that are common to schools (Bryk \& Raudenbush, 2002).

Random effects-measures of factors that vary with individuals or schools (Bryk \& Raudenbush, 2002).

Covariates-variables that are correlated with the outcomes of interest and the explanatory variables which must be controlled in order to assure the outcomes have a relationship to the explanatory variables (Bryk \& Raudenbush, 2002). Chapter Four focuses on a discussion of the results of the study. 


\section{CHAPTER IV}

\section{FINDINGS}

\section{Introduction}

A compelling question being asked by policy makers, teacher educators, school administrators, and business leaders is related to whether or not National Board Certified Teachers (NBCTs) are more effective than other teachers who are not certified by the National Board based upon their quality teaching and their students' learning. This chapter provides a description of the results of the quantitative data analyses.

The purpose of this study was to examine the relationship between teachers in Kentucky who had obtained certification through the National Board for Professional Teaching Standards (NBPTS) and the achievement of their students. Specifically, to determine if there was a statistically significant difference between the 2009 Kentucky Core Content Test (KCCT) results in reading and mathematics for third-grade students of National Board Certified Teachers (NBCTs) and students of teachers who did not hold National Board Certification.

\section{Participant Demographics}

Fifty-three NBCTs were identified as classroom teachers from a list of 171 NBCTs who had been certified as either early- or middle-childhood generalists 
for this study. From that number, 27 were eliminated because they did not teach third grade in a self-contained classroom during the 2008-09 school year. Selfcontained classrooms are described as those in which a teacher would teach both reading and mathematics to the students assigned to that teacher.

A total of 20 NBCTs who taught in self-contained, third-grade classrooms agreed to participate in this study by returning their student numbers, and the data of 20 comparison teachers identified by Kentucky Department of Education and school district personnel were also used in this study. The NBCTs were employed in 15 school districts throughout the Commonwealth of Kentucky and these districts were representative of urban, rural, and suburban areas of the state. Only one male teacher was identified for the study.

\section{Results}

First, descriptive statistics are presented on variables that were measured on teachers and students. Then inferential statistics are presented that address the major research question of the study: Are there differences in the reading and mathematics achievement of third-grade students taught by NBCTs compared to students taught by the control teachers who were not National Board certified?

\section{Descriptive Statistics on Study Variables}

The researcher collected data on the achievement of 811 students from 40 teachers: 20 NBCTs and 20 control teachers. Students from each of the 40 teachers were measured on several demographic variables as well as achievement in reading and mathematics. The only variables measured on teachers were two variables measured on the NBCTs group. For those 20 
teachers, the average number of years of teaching experience was $M=18.6$, and the average number of years with National Board Certification was $M=6.0$. The actual range of the number of years of teaching experience was 11-28 years and the range of the number of years the NBCTs had held National Board Certification was $2-9$ years.

Table 2 shows numbers and percentages for several student variables. The numbers of students in the two groups were similar; there were only a few more in the National Board group. The gender percentages of children were about the same in both groups: close to $50 \%$ male and $50 \%$ female.

The great majority of children (close to $90 \%$ ) were Caucasian in ethnicity, with African American being the next largest group. Regarding lunch status, more students in the control teacher group had free lunch status than students in the NBCTs group. There were a statistically significantly larger percentage of low socioeconomic (SES) students in the control classrooms than the classrooms taught by NBCTs. The control classrooms had $54 \%$ of student on free lunch, compared to $41 \%$ in the NB classrooms, $X^{2}(2)=21.54$, $p<.001$

\section{Table 2}

Frequency Distributions for Student Variables: Group, Sex, Ethnicity,

\section{Free/Reduced Lunch Status}

\begin{tabular}{|c|c|c|}
\hline $\begin{array}{c}\text { Free/Reduced } \\
\text { Lunch Status }\end{array}$ & $\mathrm{n}$ & \multicolumn{1}{c|}{$\%$} \\
\hline NB & 416 & 51.1 \\
Control & 398 & 48.9 \\
Total & 814 & 100.0 \\
\hline
\end{tabular}


Table 2 (Continued)

\begin{tabular}{|c|c|c|c|c|c|}
\hline & & \multicolumn{4}{|c|}{ Group } \\
\hline & & \multicolumn{2}{|c|}{ NB } & \multicolumn{2}{|c|}{ Control } \\
\hline & & $\mathrm{n}$ & $\%$ & $\mathrm{n}$ & $\%$ \\
\hline \multirow[t]{3}{*}{ Sex } & Male & 205 & $49.5 \%$ & 200 & $50.3 \%$ \\
\hline & Female & 209 & $50.5 \%$ & 198 & $49.7 \%$ \\
\hline & Total & 414 & $100.0 \%$ & 398 & $100.0 \%$ \\
\hline
\end{tabular}

\begin{tabular}{|ll|r|r|r|r|}
\hline \multirow{2}{*}{} & & \multicolumn{4}{|c|}{ Group } \\
\cline { 3 - 6 } & \multicolumn{2}{|c|}{ NB } & \multicolumn{2}{|c|}{ Control } \\
\cline { 2 - 6 } & $\mathrm{n}$ & \multicolumn{1}{c|}{$\mathrm{n}$} & \multicolumn{1}{c|}{$\%$} \\
\hline Ethnic Group & Asian & 5 & $1.2 \%$ & 5 & $1.3 \%$ \\
& African American & 29 & $7.0 \%$ & 13 & $3.3 \%$ \\
& Hispanic & 12 & $2.9 \%$ & 11 & $2.8 \%$ \\
& Other & 7 & $1.7 \%$ & 10 & $2.5 \%$ \\
& Caucasian & 360 & $87.2 \%$ & 358 & $90.2 \%$ \\
\hline
\end{tabular}

\begin{tabular}{|cl|c|c|c|c|}
\hline \multirow{2}{*}{} & & \multicolumn{4}{|c|}{ Group } \\
\cline { 3 - 6 } & \multicolumn{2}{|c|}{ NB } & \multicolumn{2}{c|}{ Control } \\
\cline { 3 - 7 } & & $n$ & $\%$ & $n$ & $\%$ \\
\hline \multirow{2}{*}{ Lunch Status } & Pay & 175 & $42.1 \%$ & 153 & $38.4 \%$ \\
& Reduced & 72 & $17.3 \%$ & 32 & $8.0 \%$ \\
& Free & 169 & $40.6 \%$ & 213 & $53.5 \%$ \\
\hline
\end{tabular}

Inferential Statistical Tests Related to Reading and

\section{Mathematics Performance}

Several tests were calculated comparing the reading and mathematics performance of third-grade students from two groups: (a) those taught by 
NBCTs, and (b) those taught by control teachers who came from the same school or district or region.

\section{Randomized MANOVA, ANOVA and}

\section{ANCOVA on Individual Student Data}

A two-group multivariate analysis of variance (MANOVA) was performed. The independent variable had two levels, NB and control. The dependent variables were Kentucky Core Content Test (KCCT) scale scores in reading and mathematics. Table 3 shows means and standard deviations on the dependent variables for the two student groups. Reading and mathematics performance were similar for the teacher groups. The MANOVA revealed no significant difference between the reading and mathematics performance of students taught by NB and control teachers, using Hotelling's trace criterion $=.001, F(2,812)=$ $0.37, p=.69$. Hotelling's trace criterion is a statistical test utilized in multivariate

\section{Table 3}

Descriptive Statistics for Grade 3 KCCT Reading and Mathematics Scores for NB and Control Teachers

\begin{tabular}{|ll|c|c|c|}
\hline & Group & Mean & SD & N \\
\hline Reading & NB & 358.89 & 15.64 & 413 \\
& Control & 358.20 & 17.58 & 398 \\
& Total & 358.55 & 16.61 & 811 \\
\hline Mathematics & NB & 358.99 & 17.68 & 413 \\
& Control & 358.48 & 18.83 & 398 \\
& Total & 358.74 & 18.24 & 811 \\
\hline
\end{tabular}


procedures to make a determination on whether or not the means of two classes or groups differ in discriminate functions (Kirk, 1995).

\section{Inferential Statistical Tests Related to}

\section{Reading and Mathematics Performance}

Several tests were calculated comparing the reading and mathematics performance of third-grade students from two groups: (a) those taught by NBCTs, and (b) those taught by control teachers who came from the same school or district or region.

\section{Randomized MANOVA, ANOVA and}

\section{ANCOVA on Individual Student Data}

A two-group multivariate analysis of variance (MANOVA) was performed. The independent variable had two levels, NBCTs and control teachers. The dependent variables were Kentucky Core Content Test (KCCT) scale scores in reading and mathematics. Table 3 shows means and standard deviations on the dependent variables for the two student groups. Reading and mathematics performance were similar for both of the teacher groups. The MANOVA revealed no significant difference between the reading and mathematics performance of students taught by NBCTs and the control teachers. Hotelling's trace criterion = $.001, F(2,812)=0.37, p=.69$.

As an additional check, analyses of variance (ANOVA) were performed on each separate dependent variable. Again, there was no significant difference between NB and control for either reading $(F(1,811)=0.32, p=.57)$ or mathematics $(F(1,810)=0.17, p=.68)$. 
Because student data can be affected by demographic variables, test score data were compared using two control variables. These two variables were ethnicity and socioeconomic status. Ethnicity was defined as a dichotomy, with Caucasian students coded 1 and non-Caucasian students (e.g., AfricanAmerican and other groups) coded 0 . Socioeconomic status was defined by the variable free and reduced lunch status, with pay for lunch coded 1 and reduced or free lunch coded 0 . Table 4 shows adjusted means for the student groups for both tests.

Table 4

Descriptive Statistics for Grade 3 KCCT Reading and Mathematics Scores for NBCTs and Control Teachers Controlling for Ethnicity and Socioeconomic Status

\begin{tabular}{|l|c|c|c|c|}
\hline \multirow{2}{*}{ Group } & \multirow{2}{*}{$\begin{array}{c}\text { Reading } \\
\text { Adjusted Mean }\end{array}$} & \multirow{2}{*}{ Std. Error } & Lower Bound & Upper Bound \\
\cline { 4 - 5 } & 358.90 & .81 & 357.31 & 360.50 \\
NB & 358.30 & .83 & 356.68 & 359.93 \\
\hline
\end{tabular}

\begin{tabular}{|c|c|c|c|c|}
\hline \multirow[t]{2}{*}{ Group } & \multirow{2}{*}{$\begin{array}{l}\text { Mathematics } \\
\text { Adjusted Mean }\end{array}$} & \multirow[b]{2}{*}{ Std. Error } & \multicolumn{2}{|c|}{$95 \%$ Confidence Interval } \\
\hline & & & Lower Bound & Upper Bound \\
\hline NB & 359.09 & .89 & 357.33 & 360.84 \\
\hline Control & 358.54 & .91 & 356.76 & 360.33 \\
\hline
\end{tabular}

Note. Adjusted means were obtained in analyses of covariance, controlling for ethnicity and free/reduced price lunch status.

The data were adjusted for the two controls and, as expected, were not the same as the means presented in Table 3. Analyses of Covariance 
(ANCOVA) revealed no significant difference between the student groups: (a) for reading, $F(1,805)=0.27, p=.61$, (b) for mathematics, $F(1,804)=0.18, p=.67$.

\section{ANOVA and ANCOVA on Aggregated Data}

Rather than using individual students as the unit of analysis, data were also analyzed in a different way. This involved aggregating the student data for each teacher and then analyzing the mean reading and mathematics scores associated with the teachers. Three sets of analyses were performed. First, one way ANOVA were performed with the independent variable group, NBCTs and control teachers, and the dependent variables, reading and mathematics mean scores. Then, dependent $t$ tests were calculated, with a comparison of the matched NBCTs and control teachers. Finally, repeated measures ANOVA were calculated, using average student socio-economic status and ethnicity as covariates.

Table 5 shows descriptive statistics on the aggregated data. The numbers of cases are reduced to the numbers of teachers: 20 NBCTs and 20 control teachers. There were very similar scores in reading and mathematics for the two teacher groups. None of the tests performed yielded any significant differences between the groups. Table 6 summarizes inferential statistical results. 


\section{Table 5}

Descriptive Statistics for Grade 3 KCCT Reading and Mathematics

\section{Scores Aggregated for $20 \mathrm{NB}$ and 20 Control Teachers}

\begin{tabular}{|l|l|c|r|r|c|}
\hline \multicolumn{2}{|c|}{} & N & Mean & Std. Deviation & $\begin{array}{c}\text { Std. Error } \\
\text { of the Mean }\end{array}$ \\
\hline \multirow{2}{*}{ Reading } & NB & 20 & 358.85 & 3.60 & .80 \\
\cline { 2 - 6 } & Control & 20 & 358.23 & 4.12 & .92 \\
\hline \multirow{2}{*}{ Mathematics } & NB & 20 & 359.10 & 5.18 & 1.16 \\
\cline { 2 - 6 } & Control & 20 & 358.51 & 7.10 & 1.57 \\
\hline
\end{tabular}




\section{Table 6}

Summary of Inferential Statistical Tests for Grade 3 KCCT Reading and

Mathematics Scale Scores Aggregated for 20 NB and 20 Control Teachers

\begin{tabular}{|c|lc|lc|}
\hline Test & \multicolumn{2}{|c|}{ Obtained test statistics } & \multicolumn{1}{c|}{$\begin{array}{c}\text { Obtained probability } \\
\text { for tests }\end{array}$} \\
\hline $\begin{array}{c}\text { One-way ANOVA } \\
\text { with the teacher } \\
\text { group as the } \\
\text { independent } \\
\text { variable }\end{array}$ & Reading & Mathematics & $\underline{\text { Reading }}$ & Mathematics \\
\hline $\begin{array}{c}\text { Dependent } t \text { tests with } \\
\text { matched NBCTs and } \\
\text { control teachers }\end{array}$ & Reading & Mathematics & $\underline{\text { Reading }}$ & Mathematics \\
\hline $\begin{array}{c}\text { Repeated measures } \\
\text { ANOVA with matched } \\
\text { NBCTs and control } \\
\text { teachers, covariate } \\
\text { SES (lunch status) }\end{array}$ & $F(19)=0.65$ & $t(19)=0.28$ & $p=.53$ & $p=.78$ \\
\hline $\begin{array}{c}\text { Repeated measures } \\
\text { ANOVA with matched } \\
\text { NBCTs and control } \\
\text { teachers, covariate } \\
\text { ethnicity (proportion of } \\
\text { students that were } \\
\text { White) }\end{array}$ & $F(1,18)=0.55$ & $F(1,18)=.64$ & $p=.47$ & $p=.44$ \\
\hline
\end{tabular}

Note. All tests involved comparing NB and control teachers, and no test was statistically significant.

\section{Additional Tests of Study Variables}

In addition to the tests reported above, several additional inferential statistical tests were performed on the data collected for the study. They were performed in order to fully explore the study data. 


\section{Correlation of Teaching Experience, Years}

\section{Certification and Student Performance}

The researcher obtained information related to the number of years of teaching experience each of the NBCTs had completed as well as the number of years the NBCTs had held National Board certification. This was done by accessing the data base of certified teachers and National Board Certified Teachers from the Kentucky Education Professional Standards Board website (Kentucky Education Professional Standards Board, 2009). For the aggregated data set, these variables were correlated with student means on reading and mathematics. The correlation coefficients for the years experience as a teacher and student performance were: (a) reading, $r=.19, p=.43$, (b) mathematics, $r=.03, p=.92$. The correlation coefficients for the years of National Board Certification and student performance were: (a) reading, $r=-.06, p=.80$, (b) mathematics, $r=-.17, p=.48$. There were no statistically significant relationships between test score data and the experience level of the NBCTs.

\section{Multiple Regression of Individual}

\section{Reading and Mathematics Scores}

An ordinary least squares multiple regression was performed with the reading scores of individual students as the dependent variable. Predictors were the variables of sex, ethnicity, free or reduced lunch status, and group (NBCTs or control teachers). The full model containing all of the predictors was statistically significant $(F(4,753)=5.47, p<.05)$ and accounted for $2.8 \%$ of the variance.

Higher reading scores were associated with Caucasian ethnicity, high SES (not 
eligible for free or reduced lunch), and female gender. The teacher group was not a statistically significant variable. Although $2.8 \%$ of the variance was explained by the predictors, this implied that $97.2 \%$ of the variance in reading scores was unexplained. This result was consistent with the state assessment results for reading scores (Kentucky Department of Education, 2009).

Mathematics scores were analyzed in a regression using the same predictors. The full model containing all of the predictors was not statistically significant $(F(4.752)=1.99, p=.09)$ and accounted for $1.0 \%$ of the variance, leaving $99 \%$ of the variance in mathematics scores unexplained.

\section{Socioeconomic Status Effects}

\section{on Test Scores}

In the previous analyses, SES was controlled as a covariate. However, it was also explored as a variable of interest to determine how it might have affected test scores. Analyses of variance (ANOVA) were performed on individual student test scores using SES as an independent variable.

First, a two-way factorial analysis of variance was performed with the reading score as the dependent variable. The independent variables were teacher group (NBCTs and control teachers) and student SES (paid lunch, reduced price lunch, or free lunch). Two statistically significant effects were found: (a) a main effect of SES, $F(2,807)=8.64, p<.001$; and, (b) a SES-bygroup interaction effect, $F(2,807)=15.53, p<.001$. The interaction effect revealed that reading performance was affected by the combination of SES and teacher group. For more affluent students (i.e., those who paid for their lunch) 
the reading performance was higher in the NBCTs' classrooms $(M=364.62)$ than in the control classrooms $(M=356.99)$. However, for the lowest SES group (students eligible for free or reduced-price lunch), the reading performance was lower in the NBCTs' classrooms $(M=352.81)$ than in the control teachers' classrooms $(M=358.79)$.

When a two-way ANOVA was performed with mathematics scores as the dependent variable, and teacher group and student SES as independent variables, a similar pattern was evident. Two statistically significant effects were found: (a) a main effect of SES, $F(2,806)=4.91, p<.01$; and, (b) a SES-bygroup interaction effect, $F(2,806)=26.00, p<.001$. For more affluent students (i.e., those who paid for their lunch) the mathematics performance was higher in the NBCTs' classrooms $(M=365.48)$ than in the control teachers' classrooms $(M=354.87)$. However, for the lowest SES group (students eligible for free or reduced-price lunch), the mathematics performance was lower in the NBCTs' classrooms $(M=352.65)$ than in the control teachers' classrooms $(M=360.62)$. 
Comparison of Study Data with

Commonwealth of Kentucky

Average Scale Scores

Data from the study groups were compared with the state average scale scores for third-grade reading and mathematics. Table 7 shows the mean scores. For the NBCTs group, student performance was significantly higher than the state averages for both subjects: (a) reading, $t(414)=23.30, p<.001$, and (b) mathematics, $t(413)=26.50, p<.001$. Similarly, for the control teachers

\section{Table 7}

Comparison of Grade 3 KCCT Reading and Mathematics Scores with

Commonwealth of Kentucky Average Scores

\begin{tabular}{|c|c|c|}
\hline & Group & Mean \\
\hline \multirow[t]{2}{*}{ Reading } & NB & 359 \\
\hline & State & 341 \\
\hline & Control & 358 \\
\hline & State & 341 \\
\hline \multirow[t]{2}{*}{ Mathematics } & NB & 359 \\
\hline & State & 336 \\
\hline & Control & 358 \\
\hline & State & 336 \\
\hline
\end{tabular}


group, student performance was significantly higher than the state averages:

(a) reading, $t(397)=19.52, p<.001$, and (b) mathematics, $t(397)=23.82$, $p<.001$

\section{Random Effects ANOVA of Reading and Mathematics}

Random effects ANOVA were performed with the reading and mathematics scores as the dependent variables and the student group as the independent variable. Student group in this context meant each of the 40 groups of students who were assigned to the 40 teachers in the study. The purpose of this analysis was to determine what proportion of the variance in test scores was attributed to student group and what proportion was attributed to the individual student. A measure of effect size for random effects ANOVA, the intraclass correlation, was calculated. For the variable of reading, the intraclass correlation was .003 , indicating less than $1 \%$ of the variance was due to the group with which the student was associated. For the variable of mathematics, the intraclass correlation was .064 , indicating about $6 \%$ of the variance was due to group differences. Both of these numbers reveal that most of the variance in scores was due to individual student factors rather than variables measured at the classroom level. Therefore, multi-level analysis of data (e.g., hierarchical linear modeling) was not pursued with these data. There was no evidence that students of NBCTs and students of non-NBCTs differed in achievement.

\section{Summary of the Data Analysis}

The main purpose of the study was to determine if student scores in thirdgrade reading and mathematics on the KCCT were systematically different for 
students who were taught by Kentucky teachers with National Board Certification as compared to Kentucky teachers who did not hold National Board Certification. Data were analyzed in a variety of ways, both at the individual student level and at the group level. In every comparative analysis, with the exception of low SES students (those eligible for free or reduced price lunch), there were no statistically significant differences found between NBCTs and teachers who were not National Board Certified. A major consideration for the findings of this study, which should impact its potential for implications, would be the limited sample size.

Chapter Five includes an in-depth discussion of the summary and conclusion of the study based upon the data analysis and research for the study. 


\section{CHAPTER V}

\section{SUMMARY AND CONCLUSIONS}

This study examined how the third-grade students of National Board Certified Teachers (NBCTs) in Kentucky performed on the 2009 Kentucky Core Content Test (KCCT) in reading and mathematics compared to the students of teachers who were not National Board Certified. Specifically, this quantitative study addressed the following research questions:

1. Is there a statistically significant difference in achievement in reading between end of primary students assigned to National Board Certified Teachers (NBCTs) and teachers who are not NBCTs?

2. Is there a statistically significant difference in achievement in mathematics between end of primary students assigned to NBCTs and teachers who are not NBCTs?

3. For NBCTs, does number of years in which they have been National Board Certified have a statistically significant positive correlation with end of primary student performance in reading and mathematics?

The availability of the data necessary for this study is central to this discussion. The researcher encountered difficulties in obtaining the data on multiple levels. The small sample size resulted in built in limitations for the study. 
The analysis was based upon a limited framework and the examination of student performance utilized only one year of student data.

Initially, the Kentucky Education Professional Standards Board (EPSB) provided a list of NBCTs certified as Early Childhood Generalists and Middle Childhood Generalists; however, there was no method available to determine what grade these teachers taught and whether or not they taught reading and mathematics. The list of NBCTs did not indicate in what year the teachers obtained this certification or their years of teaching experience.

The researcher utilized the EPSB's website to enter each NBCT's name and district individually to determine teaching assignments and years of experience. The next step was to go back to the list of Kentucky's NBCTs from the EPSB website and find the names of the participants under the year they were certified.

In addition, a major problem which impacted the data collection was the lack of connection between the teacher of record and student achievement results at the Kentucky Department of Education. The existing data set of student scores on the KCCT were not grouped according to the teacher of record, only by a state student identification (SSID) number. NBCTs and participating school districts were willing to assist in providing the SSIDs and whether or not the participating teachers taught in self-contained third-grade classrooms, teaching both reading and mathematics to their students.

This limited data base resulted in a time consuming process of hand matching the students to their teachers and the KDE staff had to search for 
student demographic variables based on the SSID numbers. Another limitation of the study was the lack of longitudinal data and norm-referenced test (NRT) results in Kentucky to this point.

The limitations on the data made it difficult to detect differences between the NBCTs group and the non-NBCT's. In all stages of the analysis of the data, only one of the tests performed yielded any significant differences between the NBCTs and the comparison group. The analysis of the data indicated no significant difference between the student scores of the two groups with the exception of socioeconomic status (SES).

Although the students of the NBCTs were slightly higher in both reading and mathematics, the difference was within the standard deviation and was not determined to be a statistically significant difference. There were also no statistically significant relationships between the test results and the NBCT's years of experience or the number of years the NBCTs had been certified.

Among the students, the higher scores were linked to white ethnicity, students who were not eligible for free or reduced lunch, and females. This trend was evident for both the students of the NBCTs and the students of the control teachers. This is also a common finding among all districts in the state.

The only test which yielded any differences between the two groups was in the area of students eligible for free lunch which was discussed in Chapter Four. In this area, two statistically significant effects were found which revealed that reading and mathematics scores were slightly higher for the students who were not eligible for free or reduced price lunch who were assigned to NBCTs 
compared to students who were not eligible for free or reduced price lunch assigned to teachers who did not hold National Board Certification. However, the reading and mathematics scores were slightly lower for students who were eligible for free or reduced price lunch who were assigned to NBCT than those students who were eligible for free or reduced price lunch assigned to teachers who did not hold National Board Certification. In other words, the NBCTs' higher (SES) students scored higher than the higher SES students assigned to the control teacher. And the lower SES students assigned to the control teachers scored higher than the lower SES students assigned to NBCTs.

The studies conducted by Bealmear (2006) and Goldhaber (2004) found that NBCTs are more likely to teach gifted students and higher SES students. This study revealed that the students who were not eligible for free or reduced price lunch and who were assigned to the NBCTs scored higher than those assigned to the comparison teachers. The students who were eligible for free or reduced price lunch and who were assigned to the comparison teachers scored higher than those assigned to NBCTs. This could be the result of higher SES parents requesting NBCTs for their children. The NBCTs may or may not demonstrate the competencies and skills necessary to effectively teach low SES or diverse students.

The researcher recognized that the data collected for both the NBCTs and the control teachers revealed relatively high scale scores in both reading and mathematics. Most of these students would be considered proficient or higher according to the cut scores of the scale scores relative to performance levels as 
defined by the Kentucky Department of Education. In other words, the mean scale scores of the students of the NBCTs as well as the control or comparison teachers' students exceeded the state mean scale scores in both reading and mathematics.

This study would have been enhanced by a Value-added Model (VAM) analysis approach in order to more accurately determine student achievement growth (Sanders \& Rivers, 1996). A VAM approach to analysis relies on the results of standardized tests or a norm-referenced test (NRT). Due to the lack of an NRT in 2009, the study was limited to only one score in reading and mathematics on the KCCT, which is a criterion-referenced test, and there was no way to measure achievement growth over time. The current process for certification through the National Board for Professional Teaching Standards (NBPTS) does not require evidence of an increase in student achievement. "Including student growth measures in the certification process would vastly improve its ability to identify quality teachers" (Sanders, Ashton, \& Wright, 2005).

Cantrell, Fullerton, Kane, and Staiger (2008) echoed this suggestion in their study. These researchers suggested that a combination of the practicebased National Board Certification process along with the value-added projected student scores would be an effective way to identify exemplary teachers. "In those grades and subjects where Value-added assessments are practical, the NBPTS should consider incorporating a value-added measure as an additional sub-score contributing to their scaled scores" (Cantrell, Fullerton, Kane, \& Staiger, 2008). 
The researcher's ability to establish any differences among the two groups of teachers (NBCTs and the control teachers) was somewhat limited due to the small sample size. The analysis of the study yielded some interesting results related to NBCTs and the student achievement results of their students. However, definite conclusions should not be made related to the validity of the certification of the National Board for Professional Teaching Standards based on a single research study utilizing a small sample size. In other words, quality teaching should not be judged solely by a single score in reading and mathematics on a state test. There should be multiple student achievement data in evaluating a teacher's effectiveness.

\section{Recommendations}

This study brought to bear the weaknesses in student data collection, particularly in connecting students' assessment scores with their teacher of record. The researcher has already begun discussions with staff at the Kentucky Department of Education (KDE) related to revisions to the state's data system in the inclusion of teachers and their assigned students. Action should be taken in the near future to address this issue. Multiple assessment scores for the students which are linked to their teachers would allow researchers to make stronger statistically informed findings related to teachers' impact on learning. The commonwealth's new performance evaluation plan for teachers includes achievement gains based on longitudinal data. Some state officials were unaware prior to the passage of Senate Bill 1 that longitudinal data was unavailable for this purpose. 
Senate Bill 1, which is in effect at this time, mandates an NRT annually for students and a statewide data system to host student information longitudinally. The data would include the students' annual assessment results, their assigned teacher information, and other records (attendance, grades, and graduation data). Once this data system is in place, a VAM may be utilized for analyzing longitudinal student performance results. This data system would support more robust studies related to quality teaching and student achievement, similar to the Tennessee Value-Added Assessment System analysis of quality teaching first introduced by Sanders and Horn (1998).

Most of the schools represented in the study are located in the central section of Kentucky and some are among the average to high performing schools in the commonwealth. This was an unforeseen factor when completing the random selection from the EPSB's list of NBCTs. However, many of the commonwealth's high performing schools have a higher number of NBCTs than lower performing schools according to the list of NBCTs from the Kentucky Education Standards Board. Therefore the probability would be higher that a participating NBCT in this study would be teaching in a high performing school.

The researcher observed that most of the students in the schools participating in the study had relatively high scale scores in reading and mathematics, which included the students assigned to NBCTs and those assigned to the comparison or control teacher. This result could be explained by the concept of nesting by Bryk and Raudenbush (2002) which was discussed in Chapter Three. They explained that students in the same school may 
experience a common classroom culture, learning environment, and expectations which can cause their scores on assessments to appear to have a positive correlation. If the statistical models utilized in the analysis are not capable of taking these correlations into account, teacher effects estimates may appear to be exaggerated. This would then lead to conclusions based on false positives related to statistical significance (Bryk \& Raudenbush, 2002). The VAM analysis process addresses these correlations through student growth in achievement (Sanders \& Rivers, 1996). The researcher did not find any teacher effects in this study, so no exaggeration occurred.

Further studies in this area should review and compare the professional development opportunities of these specific schools. Many schools in the Commonwealth have implemented professional learning communities which provide teachers time to plan, analyze their common assessments, and reflect on their lessons during a common planning time. An argument could be made that the NBCTs serve as teacher leaders in their schools and that the "NBCT effect" impacts the quality of instruction throughout these schools.

As this was the first study addressing the impact of NBCTs on student achievement in Kentucky, additional studies should be undertaken which would include a broader base of participants and more student scores. Beginning in the spring of 2010, the state assessment in Kentucky included a national NRT in reading and mathematics. In the future it will be possible to utilize longitudinal data to measure achievement growth over time in a similar study. 
Ideally, a quantitative and qualitative study should be conducted in which researchers would have access to longitudinal data for NBCTs to compare non-NBCTs who have similar teaching assignments. These teachers should be interviewed to determine their leadership roles in their schools and their potential impact on classroom instruction of their peers, another consideration of the value of NBCTs.

Many school districts and states across the nation are utilizing National Board Certification as a basis for compensation beyond the level of education and years of experience. The initial rationale for this practice was to recruit capable and high quality individuals into the profession of teaching. This practice is currently being questioned due to wide sweeping budget cuts and the lack of recent empirical data to support the link between National Board Certification and quality teaching. Some states have already made cuts in the budget for National Board compensation due to the rising number of NBCTs which resulted in escalating costs.

There were 1829 NBCTs in Kentucky in 2009. Each of these NBCTs currently earns a minimum of $\$ 2000$ stipend each year for up to ten years, and would continue beyond ten years if the NBCTs are re-certified. These salary supplements account for over 3.6 million dollars from Kentucky's budget annually. In addition, the commonwealth had been funding a mentoring program, including the cost of substitute teachers to provide five release days and payment for two noncontract work days for National Board Candidates to work on their portfolio entries and prepare for the assessment center exercises. Funds 
were also provided to pay mentors for candidates. The cost for these services for candidates is approximately $\$ 1400$ per candidate. During the 2009 General Assembly, the legislators cut the two noncontract days from the budget. The void of empirical studies related to the impact of NBCTs on student achievement may leave the state financial supports for the National Board initiative in Kentucky vulnerable to further cuts in salary supplements and the mentoring program.

In Chapter Two, the researcher discussed the National Board for Professional Teaching Standards (NBPTS) issuing a request for proposals (RFP) in 2002 for researchers to analyze the impact of NBPTS certification on teaching as a profession and on student achievement. Several studies were funded by NBPTS through 2006. Since that time, there have been very few studies which linked NBPTS certification with student achievement. If National Board Certification is to represent quality teaching, there is a need for larger studies in Kentucky and elsewhere to validate a statistically significant difference in the achievement outputs of NBCTs' students compared to students who are not assigned to NBCTs.

Three large studies reviewed in Chapter Two concluded that National Board Certification was linked to increased student achievement and confirmed that National Board Certification was an indicator of quality teaching (Vandevoort, Amrein-Bearsley, \& Berliner, 2004; Cavalluzzo, 2004; and Goldhaber \& Anthony, 2004). Other studies did not find such a relationship (Sanders, Ashton, \& Wright, 2005 and Bealmear, 2006). However, Vandevoort, Amrein-Bearsley, and 
Berliner (2004) did warn against false positives related to National Board candidates' ability to write effectively. In other words, a highly effective teacher may not possess the ability to communicate in writing in a proficient manner. At the same time, a teacher who is not as effective in the classroom may be more articulate in written communication (Vandevoort, Amrein-Bearsley, \& Berliner, 2004).

The Goldhaber and Anthony (2004) study found that completing a master's degree was statistically related to teachers' effectiveness. The researchers also found that NBPTS certification was also a statistically significant measure of teacher quality. They suggest that the National Board certification process may indeed be a validation for teachers who were already considered effective. They also recommend that NBCTs be assigned to struggling students rather than high performing schools in affluent neighborhoods (Goldhaber \& Anthony, 2004).

Darling-Hammond and Ducommun (2010) noted that there would be an impact on narrowing the achievement gap if students with the highest need had equitable access to NBCTs for their teachers, recognizing that NBCTs are considered to be the more accomplished, well-prepared, and experienced teachers. The researchers verified the use of National Board Certification as a valid basis for additional compensation and that the VAM process be included in evaluating instructional methods and teachers' evaluations (Darling-Hammond \& Ducommun, 2010). 
While the results of this study did not yield the anticipated positive correlation between NBCTs and student achievement, the data does reveal that the mean scale scores of the students assigned to NBCTs were at the proficient level according to the cut scores and above the performance of the mean scores of students across the commonwealth. The fact that the students of the control teachers also scored at this level could very well be explained by the culture and professional practices at their schools, a "school effect" rather than a "teacher effect." If teachers are continuously monitoring the progress of their students, planning effective lessons, analyzing student products, and reflecting upon the impact of their instruction on student results in professional learning communities, then they would be implementing the practices and theory behind the National Board Certification process.

In summary, the findings of this study suggest that the students of NBCTs performed higher than the commonwealth average on the $2009 \mathrm{KCCT}$ in both reading and mathematics. Research studies reviewed in the study suggested that states and school systems recognize National Board Certification as an indicator of the teacher quality and use this certification as a basis for pay increases or additional compensation. If this additional pay attracts effective teachers into the teaching profession, then students will truly benefit. School districts should plan and implement training and job-embedded professional development which targets the pedagogy and instructional strategies that are used by NBCTs. 
Through the identification of available data, the researcher for this study discovered a trend for Kentucky's NBCTs. Out of 171 NBCTs certified as Early Childhood Generalists or Middle Childhood Generalists, only 53 were classroom teachers. The remaining NBCTs were serving as resource teachers, instructional coaches, or other district-wide positions. They no longer had direct contact with students on a regular basis. There were also situations where the NBCTs were leaving one district to move to another. As NBCTs, these teachers are perceived to be an asset to districts who are filling vacancies.

In Kentucky, teachers who wish to be candidates for National Board Certification are required to have completed their master's degree prior to their application to NBPTS. Based upon the recommendations from the research of Goldhaber and Anthony (2004), indicating that a master's degree was an effective measure of teacher quality, the master's degree prerequisite may have played a role in the results of this study. Although all of the NBCTs included in this study held a master's degree, there was no data available to determine whether or not the comparison teachers also held master's degrees.

Senate Bill 1 calls for a statewide data system to track student information and achievement results, along with other student demographic information and the teachers of record. Noell and Kowalski (2010) recommended that states implement a stateside teacher and student data system which would include longitudinal student outcomes lined to teachers (Noell \& Kowalski, 2010). Once such a statewide data system is operational, to be in compliance with Senate Bill 1, the Kentucky Department of Education and the Kentucky Education 
Professional Standards Board will have the capacity to provide student and teacher data to support a more robust studies which examine the relationship between quality teaching and student outcomes.

The conceptual framework for this study centered on quality teaching and the mandate of NCLB for teachers to demonstrate competency in their assigned teaching fields. The qualities of strong intelligence, strong knowledge of content, competencies in content pedagogy, and strong knowledge of how learning takes place are assessed through the National Board Certification process. If teacher evaluations, teacher training, and professional development sessions focused on this "bundle of traits," more students would have access to quality teaching which is tightly linked to student achievement (Darling-Hammond \& Ducommun, 2010). Barber (2008) stated that it is impossible for an education system to outperform its capacity for quality teaching. The researcher examined National Board Certification as a potential identifier of effective teachers. Kentucky is investing significant funds in professional compensation for NBCTs. The salary supplements have the potential to impact student achievement if NBCTs were assigned to the students who need them most, struggling students and in classrooms within low-performing schools. 


\section{REFERENCES}

Barber, Michael. (2008). Instruction to Deliver-Fighting to transform Britain's public services. London: Methuen Publishing Ltd.

Bealmear, N. S. (2006). Perceptions of preservice and inservice teachers working toward culturally responsive teaching: $A$ self-study of a multicultural education graduate course at an urban university. Doctoral Dissertation, University of Louisville.

Bickel, Robert. (2007). Multilevel analysis for applied research: It's just regression! New York: The Guiford Press.

Bryk, A. S., \& Raudenbush, S. W. (2002). Hierarchical linear models: Applications and data analysis methods ( $2^{\text {nd }}$ ed.). Thousand Oaks, CA: Sage Publications.

Cantrell, S., Fullerton, J., Kane, T., \& Staiger, D. (2008). National board certification and teacher effectiveness: Evidence from a random assignment experiment. National Bureau of Economic Research.

Carnegie Task Force on Teaching as a Profession. (1986). A nation prepared: Teachers for the $21^{\text {st }}$ century. Princeton, NJ.

Cavalluzzo, L. C. (2004). Is national board certification an effective signal of teacher quality? Alexandria, VA: The CAN Corporation. 
Center for Teaching Quality. (2005). Measuring what matters: The effects of National Board Certification on advancing $21^{\text {st }}$ century teaching and learning. (2005). Hillsborough, NC: CTQ.

Creswell, John. (2008). Educational Research: Planning, conducting, and evaluating quantitative and qualitative research ( $3^{\text {rd }}$ ed.). Upper Saddle River, NJ: Pearson Education, Inc.

Danielson, Charlotte. (1996). Enhancing professional practice: A framework for teaching. Alexandria, VA: Association for Supervision and Curriculum Development.

Darling-Hammond, L., \& Ducommun, C. (2010, May). Recognizing and developing effective teaching: What policy makers should know and do. American Association of Colleges for Teacher Education (AACTE) Policy Brief.

Darling-Hammond, L., \& McLaughlin, M. (2000). Teacher quality and student achievement: A review of state policy evidence. Education Policy Analysis Archives, 8, 1.

Goldhaber, D., \& Anthony, E. (2004). Can teacher quality be effectively assessed? National board certification as a signal of effective teaching. Review of Economics and Statistics, 89(1), 134-150.

Guskey, T. (2002). Evaluating professional development. Thousand Oaks, CA: Corwin Press, Inc. 
Harris, D. N., \& Sass, T. R. (2007). The effects of NBPTS certified teachers on student achievement. Journal of Policy Analysis and Management, 28(1), 55-80.

Haycock, Kati. (2001). Closing the achievement gap. Educational Leadership, $58(6), 6-11$.

Kentucky Department of Education. (2010). Retrieved January 23, 2010, from http://www.education.ky.gov/KDE/Administrative+Resources/Testing+and +Reporting +/Reports/No+Child+Left+Behind+Reports/default.htm.

Kentucky Education Professional Standards Board (KEPSB). (2009). Retrieved April 20, 2009, from http://www.kepsb.netdocuments/Cert/028.pdf.

Kirk, R. E. (1995). Experimental design: Procedures for the behavioral sciences ( $3^{\text {rd }}$ ed.). Pacific Grove, CA: Brooks/Cole.

Legislative Research Commission. (1994). A citizen's handbook: The Kentucky Education Reform Act. Frankfort, KY.

McCaffrey, D., Lockwood, J. R., \& Koretz, D. (2003). Evaluating value-added models for teacher accountability. Rand Corporation. Retrieved August 25, 2010, from http://www.rand.ort/publications/MG/MG158/.

National Board for Professional Teaching Standards (NBPTS). (2009). A research guide on national board certification of teachers. Retrieved June 10, 2009, from www.nbpts.org/.

National Commission on Teaching and America's Future. (1996). What matters most: Teaching for America's future. New York. 
National Research Council of the National Academies. (2008). Assessing accomplished teaching: Advanced-level certification programs. Congress.

Noell, G., \& Kowalski, P. (2010, May). Using longitudinal data systems to inform state teacher quality efforts. American Association of Colleges for Teacher Education (AACTE) Policy Brief.

Odden, A., \& Kelly, C. (1997). Paying teachers for what they know and do: New and smarter compensation strategies to improve schools. Thousand Oaks, CA: Corwin Press.

Sanders, W. L., \& Horn, S. (1998). Research findings from the Tennessee Value-Added Assessment System (TVASS) data base: Implications for educational evaluation and research. Joumal of Personnel Evaluation in Education, 12(3), 247-256.

Sanders, W. L., Ashton, J., \& Wright, S. P. (2005). Comparison of the effects of NBPTS certified teachers with other teachers on the rate of student academic progress. Cary, N.C: SAS Institute. Retrieved, from NBPTS Web site of www.nbpts.org/resources/ research.

Sanders, William L., \& Rivers, J. C. (1996). Cumulative and residual effects of teachers on future student academic achievement. (Research Progress Report). Knoxville, TN: University of Tennessee Value-Added Research and Assessment Center. 
United States Department of Education. (2002). The No Child Left Behind Act, PL 107-110. Retrieved November 30, 2009, from http://www.ed.gov/index.jhtml.

Vandevoort, L. G., Amrein-Beardsley, A., \& Berliner, D. C. (2004). National board teachers and their students' achievement. Education Policy Analysis Archives, 12, 46. 


\section{CURRICULUM VITAE}

NAME: Harrie Lynne Buecker

ADDRESS: 109 Chapman Drive

Frankfort, KY 40601

DOB: January 23,1952

EDUCATION

\& TRAINING:

B.S., Elementary Education

University of Louisville 1976

M.Ed.

University of Louisville 1980

Rank I, Administration University of Louisville 1994

Level II, Administrator Western Kentucky University 1998

Superintendent's Certification Western Kentucky University 1999

Ph.D., Education University of Louisville 2010

AWARDS: Frankfort NAACP's Outstanding Citizen of the Year 2010

Kentucky School Media Association's Award of Merit 2010 
AWARDS: Samuels Family Scholarship Recipient

University of Louisville

2010

Fellow

Center for Leadership in School Reform (CLSR with Dr. Phillip

Schlechty)

1991-1994

PROFESSIONAL SOCIETIES:

Kentucky Association of School Superintendents (KASS), Board Member Superintendents' Network Design Team

American Association of School Administrators (AASA)

Phi Delta Kappa (1988-1999)

National Middle School Association (NMSA)

Association for Supervision and Curriculum Development (ASCD)

Kentucky Association of School Administrators (KASA)

Kentucky School Boards Association (KSBA)

Kentucky State University's Regional Stewardship Committee

University of Louisville, Kentucky Principal's Academy Advisory

Committee

PUBLICATION: "Stocking Up on School"

Economic Experiences of Enterprising Teachers

1990

STATE AND NATIONAL MEETING PRESENTATIONS:

Presenter, Kentucky School Boards Association (KSBA)

February, 2000-2005

Presenter, Kentucky Association of Assessment Coordinators (KAAC) 1997-2002

Presenter, Kentucky Association of School Administrators (KASA) June 2000

Presenter, National Middle School Association (NMSA)

1999-"Standards Based Units of Study (Orlando)

1998- "Standards Based Curriculum Development" (Denver

1993-"Multi-Age Teaming" (San Antonio)

1991_"2001: A School Restructuring Odyssey," (Louisville)

Presenter, Kentucky Educational Technology Conference 2002 - "National Board for Professional Teaching Standards" 1994-"Electronic Portfolios" 
Presenter, Kentucky Department of Education (KDE) Data Conference 1994-1998-Regional Service Center trainings, Principal's Cadre trainings, Kentucky Leadership Academy Design Team, Kentucky Distinguished Educator trainer

Presenter, Kentucky Effective Schools Network Conference 1997-1999

Presenter, National Alliance Restructuring Education (NARE) 1995-2000

Presenter, Advancement Via Individual Determination (AVID) Conference (San Diego) 1999

\section{LEADERSHIP ROLES:}

Chairperson, Oldham County District Performance Evaluation Committee 1997-2006

Professional Development Coordinator and Project Lead, Leadership Development, 1997-2006

Project Lead, Oldham County Professional Compensation Plan state pilot program, 1998-Present

Project Lead, Oldham County Schools' Standards-based Curriculum Initiative, 1997-2006

Advisory Board, Jefferson Community College, Carrollton Campus, 20032007

Executive Board, Ohio Valley Association of School Administrators, 20022003

President and Executive Board, Phi Delta Kappa, 1998-2001

Team Leader, Kentucky Distinguished Educators, 1995-1996

Distinguished Educator, Crisis School, 1996-1997

Project Lead, School Based Curriculum Development, Kentucky Distinguished Educators, KDE, 1994-1997 